\title{
Monthly Output Index for the U.S. Transportation Sector
}

KAJAL LAHIRI

University at Albany, SUNY

HERMAN STEKLER

George Washington University

WENXIONG YAO

University at Albany, SUNY

PEG YOUNG

Bureau of Transportation Statistics

U.S. Department of Transportation

\begin{abstract}
In this paper, we develop a monthly output index for the U.S. transportation sector from January 1980 through April 2002, covering air, rail, water, truck, transit, and pipeline activities. Separate indexes for freight and passenger are also constructed. Our total transportation output index matches very well with the annual transportation output figures produced by the Bureau of Labor Statistics and the Bureau of Economic Analysis. The strong cyclical movements of transportation output appear to be more synchronized with the growth slowdowns in the U.S. economy than full-fledged recessions. Our index led the turning points of the six National Bureau of Economic Research-defined growth cycles over the period with an average lead time of six months at peaks and five months at troughs.
\end{abstract}

\section{INTRODUCTION}

In this paper, we develop an index of monthly economic activity for the transportation sector of the U.S. economy. In contemporary business cycle analysis, output is one of the four coincident economic indicators of the overall economy. Output refers to the physical quantity of items produced, as distinct from the sales value, which combines

KEYWORDS: transportation output, Fisher Ideal Index, business cycles, growth cycles, freight transportation. 
quantity and price. In our context, transportation output measures freight movement and passenger travel by different transportation modes. Prior to our work, there was no unique indicator to measure the output of the transportation sector on a monthly basis. The Bureau of Economic Analysis (BEA) and the Bureau of Labor Statistics (BLS) of the U.S. government produce output measures for the transportation sector on an annual basis. The Federal Reserve Board does not produce an index of production for the manufacturing sector but does for service industries.

Even though there has been considerable development of National Bureau of Economic Research (NBER)-type indicator analysis for the whole economy, little work has been done in developing sectoral indicators. While Layton and Moore (1989) have developed leading indicators for the service sector, no monthly indexes of output for particular service industries exist.

In order to construct a monthly index of output for the transportation sector, it is first necessary to determine the constituent parts of the industry. We do that in the next section. Then we discuss the output data available for each of these components of the transportation sector. We also explore possible uses of the output index in business and growth cycle analysis. The newly developed output index is then compared against the annual transportation output figures produced by BEA and BLS.

\section{COMPONENTS OF THE TRANSPORTATION SECTOR}

We base our definition of the industry on the North American Industrial Classification System (NAICS). This definition also conforms to the Transportation Satellite Accounts (TSAs) associated with the National Income and Product Accounts (NIPA).

Although transportation activities generally include Household Production of Transportation Services (HPTS) in owner-operated automobiles and in-house as well as for-hire transportation by commercial establishments, in this study we consider only for-hire commercial activities for lack of available monthly data on the other two components. Official data on transportation services, defined in either the Standard Industrial Classification codes or NAICS, are confined to establishments that pro- vide passenger and/or freight transportation services for a fee; neither in-house transportation nor HPTS are counted. ${ }^{1}$ Although market activities by NAICSdefined establishments do not cover all transportation activities, for-hire is nevertheless the most informative component of the transportation sector.

For-hire transportation includes six subsectors: air, rail, water, truck, transit and ground passenger transportation, and pipeline. Even though these subsectors are representative of economic activity in the transportation industry and are closely associated with the sectors in the satellite NIPA, a problem must be noted. These series do not include all of the subsectors in the for-hire portion of the transportation sector. The subsectors included in NAICS but excluded here are: scenic and sightseeing transportation, support activities for transportation, postal service, and couriers and messengers. The industries included correspond to NAICS codes 481 to 486 and cover $89.7 \%$ to $93.9 \%$ of total transportation between 1980 and 2000, according to the "Gross Product by Industry" table in the November 2001 issue of the Survey of Current Business.

A useful monthly index of economic activity in the transportation sector can be derived from the available series, because the subsectors they represent constitute a significant portion of the entire industry. Moreover, the transportation subsectors that we used to construct the index of transportation output account for a substantial portion of U.S. gross domestic product (GDP). The aggregate value of for-hire transportation accounted for $3.1 \%$ and $3.0 \%$ of GDP in 1992 and 1996, respectively ${ }^{2}$ (Fang et al. 1998 and 2000). Given the critical role that transportation plays in facilitating economic activity between sectors and across regions, an index of its output can be an important indicator

\footnotetext{
${ }^{1}$ Han and Fang (2000) and Chen et al. (2003) have shown the importance of in-house and household components, respectively, but their estimates are currently annual. Arguably, these two components should be included as part of transportation output when their monthly measures are developed.

${ }^{2}$ These numbers and other measures of the importance of transportation were derived from the value added of the industry. Using different concepts of the scope of the transportation industry would yield different measures of its importance, varying anywhere from $3.09 \%$ (transportation GDP) to $16.50 \%$ (transportation-driven GDP). See Han and Fang (2000).
} 
for either the current or future level of general economic activity (see Ghosh and Wolf 1997).

\section{DATA}

The total Transportation Output Index was developed from eight series. Five of these series measure the level of freight activity, and the remaining three measure the level of passenger services. The series used to measure the freight component were trucking tonnage, air revenue ton-miles, rail revenue tonmiles, ${ }^{3}$ a waterway tonnage indicator, and pipeline movements of petroleum products and natural gas. Similarly, the passenger output index was constructed from three series: air revenue passenger-miles, rail revenue passenger-miles, ${ }^{4}$ and national transit ridership. ${ }^{5}$ The sources and characteristics of all of these series are provided in appendix 1 (pages 16-23).

With the exception of pipeline, all data were available from January 1980 to April 2002. The pipeline data were available starting in January 1985 going to April 2002. The series that we used to measure pipeline transportation is constructed from data on movements of crude oil and petroleum products, consumption of natural gas, and the field production in Alaska.

Crude oil and petroleum products are moved between different Petroleum Administration for Defense Districts (PADDs), while natural gas is delivered to final users. The Alaska field production of crude oil and petroleum products is added, because it almost never enters the PADD system. ${ }^{6}$ This addition accounts for the movement within Alaska along the Trans-Alaska Pipeline from the

\footnotetext{
3 The monthly rail revenue ton-miles data were obtained by interpolating the quarterly figures. We are now working on weekly railroad data on carloads and intermodal traffic to construct a monthly series. These figures will be used to update the index.

${ }^{4}$ Due to a change in data-collection procedure, rail revenue passenger-mile (RPM) values from January 1980 to December 1985 were unusable. The RPM values for these months were backcasted based on a regression of rail RPM on rail Revenue Passengers (RP), Rail_RPM $=-27991243.120+$ $51725.329 *$ Rail_RP $-0.485 * R^{2}$ ail_RP ${ }^{2}$, estimated over January 1986 to April 2002. Adjusted $R^{2}=0.562$.

5 The transit data are monthly but are available only on a quarterly basis.

6 Alaskan petroleum used to be mostly consumed within Alaska or other PADD regions due to an export ban. This ban was lifted in the early 1990s, and now most of it is exported to Japan.
}

North Slope to the port of Valdez. However, movements of crude oil and petroleum and natural gas are measured in different units. The first is measured in millions of barrels per day while natural gas is measured in cubic feet. It is possible to combine them by converting both to tons (or Btu) with conversion factors. ${ }^{7}$ Then the converted tonnage of petroleum and natural gas are added together as the measure of total movement by pipelines. Just as with the other series, these figures are converted into index number form with 1996 equal to 100 .

In constructing the index, the weights were adjusted for the years in which the pipeline data were not available. Each series was then seasonally adjusted using the Census X-11 program. ${ }^{8}$ We used the econometric software EViews (version 3.1) for this purpose. Because all of these series measure real quantities, no price deflation was required.

\section{INDEX CONSTRUCTION}

\section{Weights for the Components Series}

The total output of the transportation industry is an aggregate of real output generated by each of the components, and thus data from the eight series were used to construct the Transportation Output Index. Each series, representing the output quantity of a transportation subsector, was converted into index number form with 1996 equal to 100.

In order to construct the Transportation Output Index, $I_{m}^{A}$ ( $A$ denotes "aggregate" and $m$ denotes the month), for the entire transportation sector, the subsector indexes were combined by assigning weights to each of the components. The weights measure the relative importance of each subsector to the entire sector. They can also be interpreted as the "price" of services provided by different modes in quantity indexes.

While there are several different ways of measuring the relative importance of each subsector, we used value-added weights from the NIPA. Here, the value-added weights are more appropriate than

\footnotetext{
7 The conversion factors were obtained from the U.S. Department of Energy (DOE) and they are presented in appendix 1. DOE has two types of conversion factors, one based on Btu and one based on mass; both yield similar estimates.

8 The X-11 program was originally developed by Shiskin et al. (1967).
} 
gross output, because transportation is an intermediate sector whose economic contribution is calculated as the difference in the values of goods being transported. This definition conforms to the concept of GDP.

Weights were obtained from the annually updated "Gross Product by Industry" table published in the Survey of Current Business (November 2001). We disaggregated airline and railroad weights into their respective freight and passenger components by using the ratio of their operating revenues for the particular year.

Figure 1 shows the historic annual weights for each component of the Transportation Output Index. Since 1981, air passenger transportation, which dominates the airline industry, has an increasing weight relative to other subsectors, and railroad freight, which dominates rail transportation, has a decreasing weight. From 1980 to 2000, airline industry and railroad transportation weights changed from $18.8 \%$ to $33.0 \%$ and $21.5 \%$ to $8.1 \%$, respectively.

Trucking maintained the greatest weight among all subsectors throughout the period, always in excess of $40.0 \%$. The weights for rail passenger, air freight, pipelines, water transportation, and public transit were always below $8.0 \%$ and changed little over this period. The graph also reflects a less freight-intensive contemporary economy in that the total weight for freight movement relative to total transportation activity has steadily shrunk from $72.3 \%$ to $61.1 \%$ between 1980 and 2000 .

\section{Fisher Ideal Index}

Given the weights, component series are aggregated into one single index using different index methods. Economic theory indicates that the preferred measure of quantity change is a geometric mean of the Laspeyres index and the Paasche index. This results in the so-called Fisher Ideal Index. The Fisher Ideal Index is one of the "superlative" aggregate indexes, which means current-weighted, while the other two are fixed-weighted using weights in a single period. The use of fixed-weighted measures for a quantity index, such as those derived from the Laspeyres quantity index, may result in "substitution bias" that overstates output growth for periods after the base year and understates growth for periods before the base year (see Landefeld and Parker (1995) for further explanation).

The tendency of substitution bias reflects the fact that those commodities for which output grows rapidly tend to be those for which prices change less proportionately. Although this bias may be small enough to be safely ignored for shorter sample periods, the output measures derived from a fixedweighted index can become increasingly subject to "weighting effects" as the time between the weighting period and the current period lengthens. A similar but opposite problem occurs with the other type of fixed-weighted index, the Paasche quantity index, which uses current period prices as weights.

The Fisher Ideal Index, which is a chain index, registers changes that fall between those of the Laspeyres and the Paasche indexes. Because of its many advantages, BEA has used this new methodology since 1996 to publish the NIPA (Landefeld and Parker 1995). The Board of Governors of the Federal Reserve Board (FRB) has also adopted the Fisher Ideal formula in constructing the Industrial Production Index since the mid-1990s (Corrado et al. 1997). Conceptually, our transportation output measure is very similar to FRB's Industrial Production Index in the sense that both measure the physical production of a sector.

The new formula for the growth of monthly transportation indexes is given by

$$
\frac{I_{m}^{A}}{I_{m-1}^{A}}=\sqrt{\frac{\sum_{j} I_{j m} P_{j y(m-6)}}{\sum_{j} I_{j m-1} P_{j y(m-6)}} * \frac{\sum_{j} I_{j m} P_{j y(m+6)}}{\sum_{j} I_{j m-1} P_{j y(m+6)}}}
$$

where

$I_{j m}$ is the output index in subsector $j$ in month $m$;

$P_{j y(m)}$ is the value-added weight for subsector $j$ in year $y$;

$y(m)$ is the year containing the month $m$.

The Transportation Output Index (Fisher Ideal) uses annual outputs weighted by previous, current, and next year prices. To compute the output quantity index as a chain-typed annually-weighted Fisher Index, we required the unit value added for both the current and the next year. While the "Gross Product by Industries" table is usually published in the November issue of the Survey of Current Business, the estimates for recent periods were obtained in 
FIGURE 1 Annual Weights for the Aggregation of Transportation

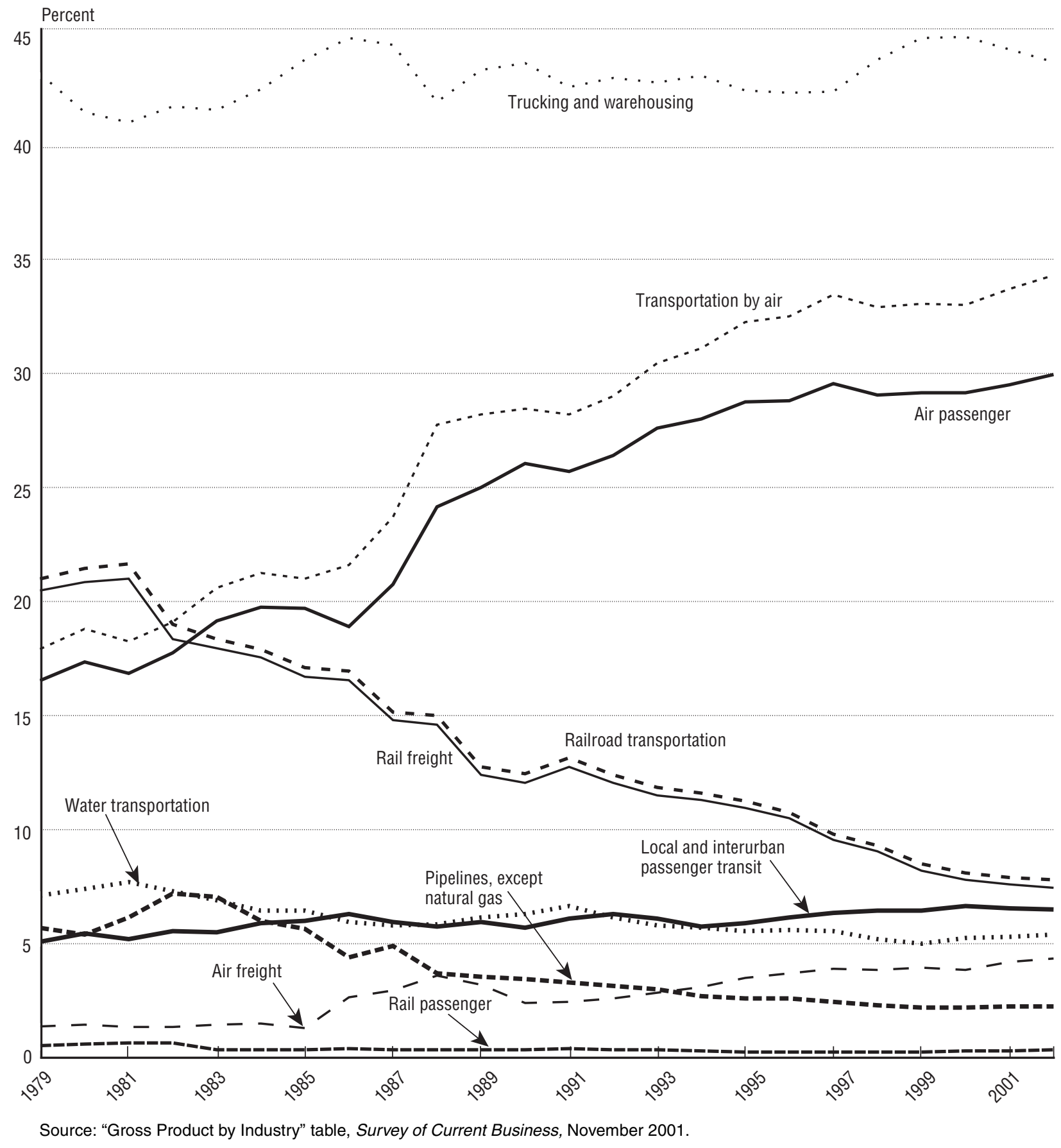

two steps. First, the industry producer price index (PPI) for each subsector of transportation (for transit, we used the consumer price index for intracity transportation, because PPI is not available for this subsector) that BLS produces on a monthly basis were extrapolated to obtain the annual averages for the current year (2002) and the next year (2003). Second, the unit value-added measures were extrapolated based on these annual averages of industry PPI. The Transportation Output Index, as well as its freight and passenger component subtotals, is computed as the cumulative product of a monthly series of these growth estimates from January 1980 onward. For $I_{0}^{A}=100$ in the base year,

$$
I_{m}^{A}=\frac{I_{m}^{A}}{I_{m-1}^{A}} \times \frac{I_{m-1}^{A}}{I_{m-2}^{A}} \times \cdots \times \frac{I_{1}^{A}}{I_{0}^{A}} \times 100
$$

Figure 2 compares the Fisher Ideal Index of total transportation output with its alternative index 
FIGURE 2 Total Transportation Index: Linked Laspeyes vs. Fisher Ideal

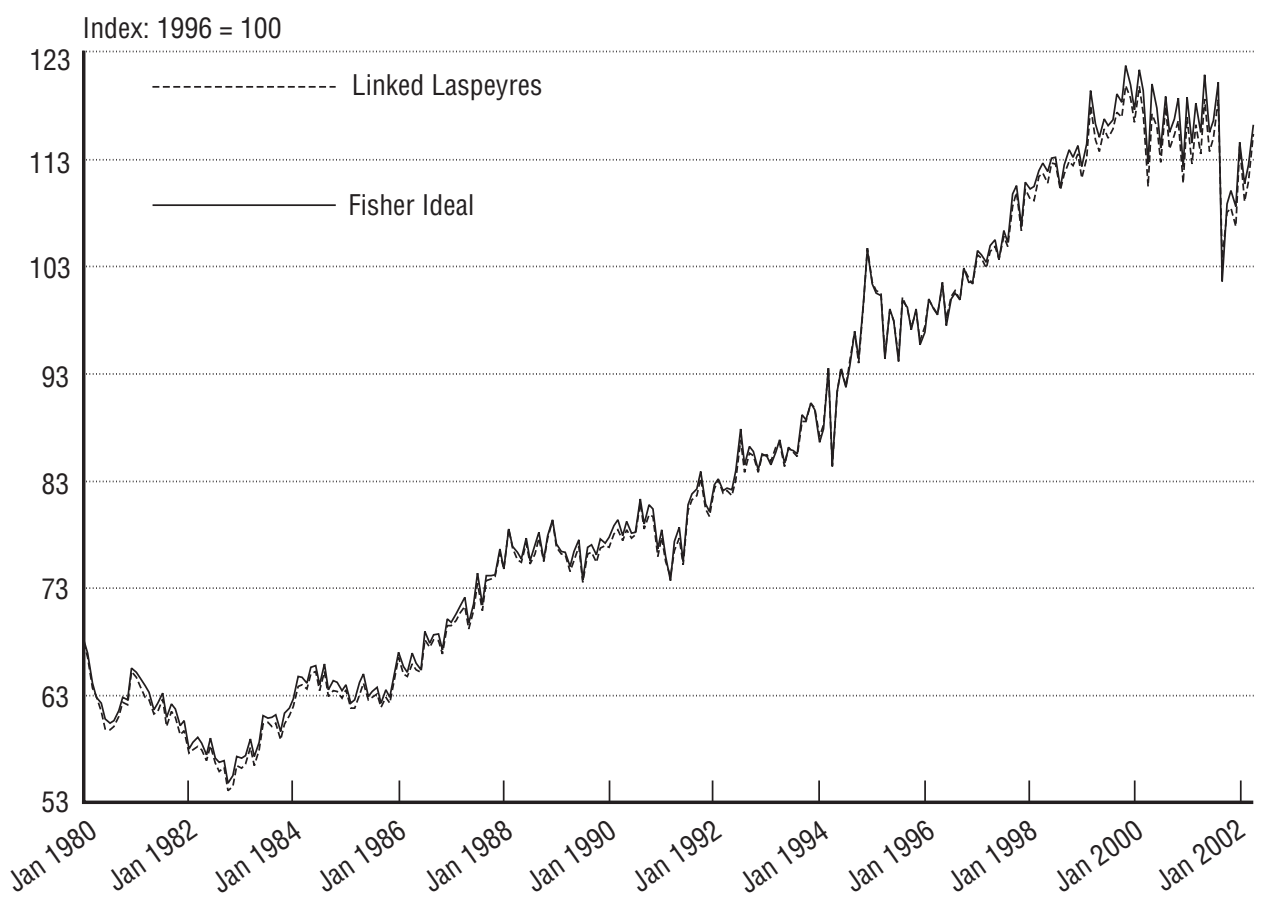

computed from the linked Laspeyres. ${ }^{9}$ They are found to be almost identical. Any difference would arise from the weights used. As seen earlier in figure 1 , the weight on the largest component, trucking, has been pretty stable in the sample period, which limits any potential substitution bias. FRB also found a similar result when they recomputed their Industrial Production Index using the Fisher Ideal Index ${ }^{10}$ (Corrado et al. 1997). However, because of its potential advantages, the transportation indexes derived from the Fisher Ideal Index were used for our analysis in this paper.

\footnotetext{
9 The standard formula for the linked Laspeyres quantity index is $I_{M}^{A}=\Sigma I_{m} \cdot p_{0} / \Sigma I_{0} \cdot p_{0}$ where $p_{0}$ is the price in the base period. (Note that we set $I_{0}=100$.) It shows changes in physical movements in the transportation sector with prices held fixed at base year values, which is 1996 here (Corrado et al. 1997). Because the public transit subsector is often supported by public subsidies, its value-added figures are sometimes negative. As a result, we had to calculate the weight assigned to this sector as the average of the ratio of its output to the total transportation industry output for 1996 . For airlines and railroads, we determined the relative amount of operating revenue obtained from transporting passengers and freight to disaggregate the weight into passenger and freight. The weights for the Laspeyres index are obtained from the 1996 TSA (Fang et al. 2000) and presented in table 1.

${ }^{10}$ We thank Professor Ariel Pakes of Harvard University for an illuminating discussion on this finding.
}

\section{THE CHARACTERISTICS OF THE INDEX}

\section{Classic Business Cycles}

The monthly values of the resulting indexes for January 1980-April 2002 are tabulated in appendix 2 (pages 24-27). The Total Transportation Output Index, the Freight Transportation Output Index, and the Passenger Transportation Output Index are presented in figures $3 \mathrm{a}$ to $3 \mathrm{c}$. Dark shaded areas represent the NBER-defined recessions in the U.S. economy and lightly shaded areas represent the

TABLE 1 Final Weight for Transportation Indexes (Linked Laspeyres)

\begin{tabular}{lrr} 
Subsector of transportation & $\begin{array}{c}1996 \text { Transportation } \\
\text { Satellite Accounts } \\
\text { (adjusted) }\end{array}$ \\
\hline Rail & $17.3 \%$ \\
$\quad$ Passenger & \multicolumn{2}{c}{$0.8 \%$} \\
$\quad$ Freight & $16.5 \%$ \\
Truck & $42.2 \%$ & \\
Water & $4.7 \%$ & \\
Air & $24.7 \%$ & \\
Passenger & \multicolumn{2}{c}{$21.3 \%$} \\
$\quad$ Freight & \multicolumn{2}{c}{$3.4 \%$} \\
Pipeline & $9.7 \%$ \\
Transit & $1.4 \%$ \\
Total & $100.0 \%$ \\
\hline
\end{tabular}

Source: Adapted from Fang et al. (2000). 
FIGURE 3 Three Transportation Output Indexes: Seasonally Adjusted

3a Total Transportation Output Index (Fisher Ideal)

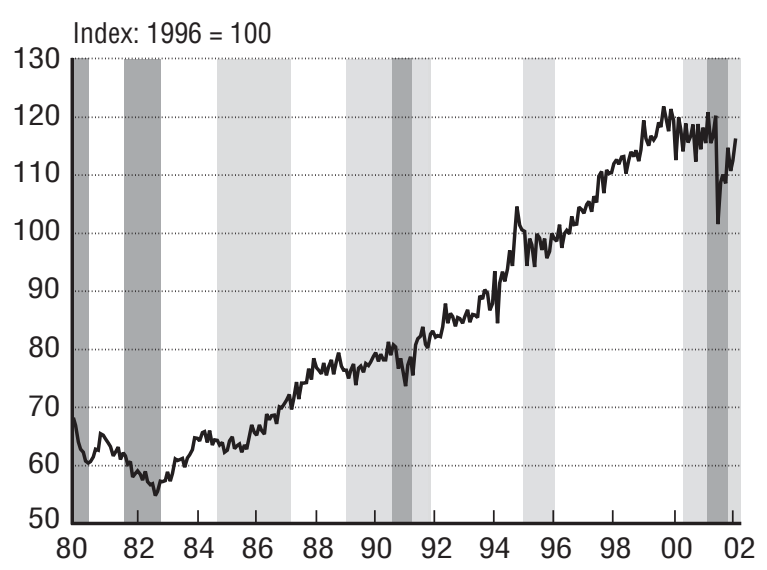

3b Freight Transportation Output Index (Fisher Ideal)
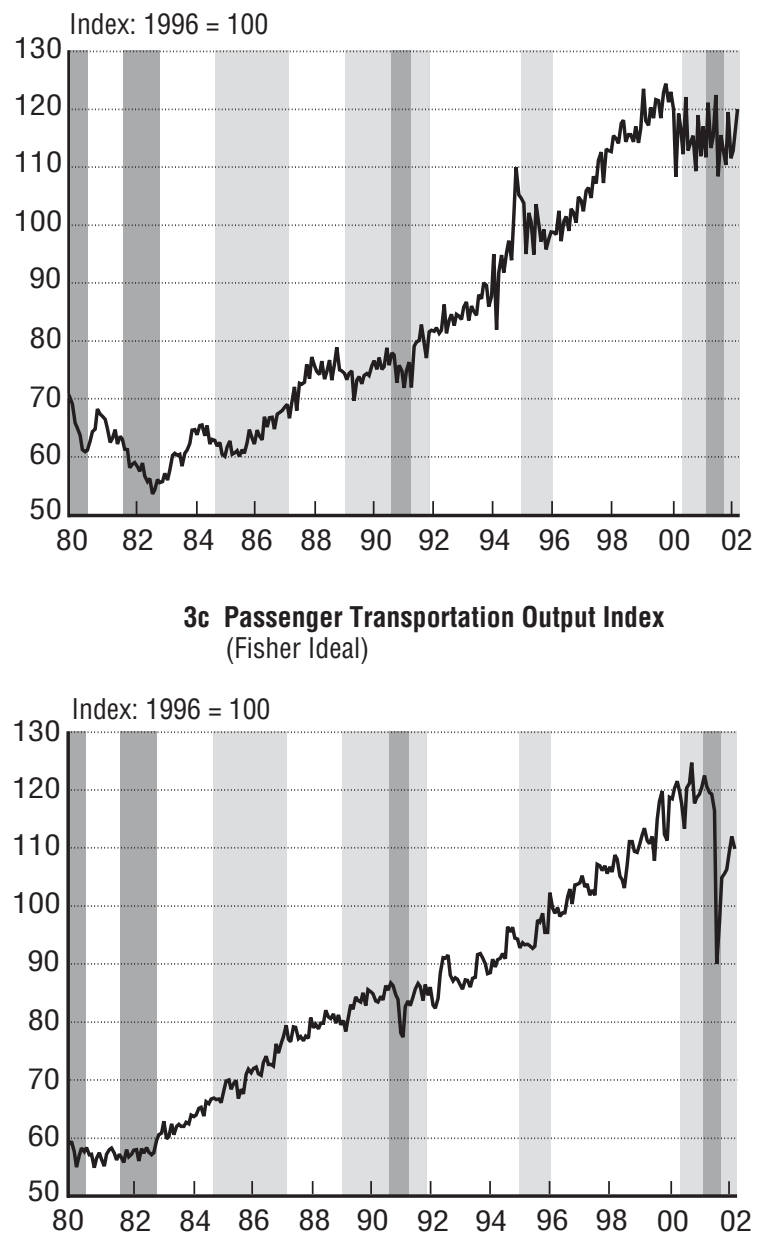

Note: Dark shaded areas represent the NBER-defined recessions in the U.S. economy; lightly shaded areas represent the NBER-defined growth cycle recessions in the economy (the trough for the latest growth slowdown has not been determined).
NBER-defined growth cycle recessions. These indexes are based on the seasonally adjusted component series that are individually graphed in appendix 1.

Certain characteristics of these indexes should be noted. First, all of them show strong upward trends, with the Total Transportation Output Index showing a compounded annual growth rate of $2.65 \%$ between January 1980 and August 2001. Both the passenger and freight indexes also grew over this period, with rates of $3.19 \%$ and $2.56 \%$, respectively. (We compared the growth rates through August 2001, because the terrorist attacks of September 11, 2001, drastically affected the passenger component of the transportation sector.) The indexes also show declines in their values, reflecting the economic recessions of July 1981-December 1982, July 1990March 1991, and March 2001-November 2001. Sharp downward movement also occurred in both the freight and passenger indexes after September 11 and was most pronounced in the passenger index. Overall, the cyclical movement of the freight index dominates that in the Total Transportation Output Index.

The peak (trough) occurs when the Transportation Output Index reaches the highest (lowest) point of its cyclical fluctuations, which would exclude from consideration some temporary positive (negative) irregular disturbances. We followed the NBER dating algorithm described in Bry and Boschan (1971, chapter 2) to identify each of the peaks and troughs. The algorithm uses a series of rules to distinguish the real peaks and troughs from spurious ones. For instance, a movement from a peak to a trough (phase) cannot be shorter than 6 months and a complete cycle must be at least 15 months long. Using these criteria, the cyclical turning points of the Total Transportation Output Index together with the NBER business and growth cycle chronologies are reported in table 2 .

Table 2 shows that cyclical peaks in the Transportation Output Index occurred prior to the economic recessions of July 1981-December 1982, July 1990-March 1991, and March 2001-November 2001. In the case of the July 1990-March 1991 recession, we defined the peak in the index to have occurred in February 1988, nearly 29 months prior to the beginning of the economic recession. After 
TABLE 2 Lead and Lag Analysis Between Transportation and the Economy

NBER-defined chronologies of economy ${ }^{1}$

\begin{tabular}{|c|c|c|c|c|c|c|c|c|c|}
\hline \multicolumn{4}{|c|}{ chronologies of economy ${ }^{1}$} & \multicolumn{6}{|c|}{ Business cycle of Transportation Output Index } \\
\hline \multirow{2}{*}{\multicolumn{2}{|c|}{ Recessions }} & \multirow{2}{*}{\multicolumn{2}{|c|}{ Growth cycle }} & \multirow{2}{*}{\multicolumn{2}{|c|}{ Chronology }} & \multicolumn{4}{|c|}{$\begin{array}{l}\text { Lead and lag of } \\
\text { transportation vs. }\end{array}$} \\
\hline & & & & & & \multicolumn{2}{|c|}{$\begin{array}{l}\text { Recessions } \\
\text { of economy }\end{array}$} & \multicolumn{2}{|c|}{$\begin{array}{l}\text { Growth cycle } \\
\text { of economy }\end{array}$} \\
\hline$P$ & $T$ & $P$ & $T$ & $P$ & $\mathrm{~T}$ & $P$ & $\mathrm{~T}$ & $P$ & $\mathrm{~T}$ \\
\hline- & Jul-80 & - & Jul-80 & - & Jul-80 & - & 0 & - & 0 \\
\hline Jul-81 & Nov-82 & Jul-81 & Dec-82 & Feb-81 & Oct-82 & -5 & -1 & -5 & -2 \\
\hline- & - & Sep-84 & Jan-87 & Aug-84 & Sep-85 & - & - & -1 & -16 \\
\hline Jul-90 & Mar-91 & Jan-89 & Dec-91 & Feb-88 & Mar-91 & -29 & 0 & -11 & -9 \\
\hline- & - & Jan-95 & Jan-96 & Dec-94 & Jul-95 & - & - & -1 & -6 \\
\hline \multirow[t]{3}{*}{ Mar-01 } & Nov-01 & Jun-00 & - & Nov-99 & Sep-01 & -16 & -2 & -7 & - \\
\hline & & & & & Mean & -17 & -1 & -5 & -7 \\
\hline & & & & & Median & -16 & -0.5 & -5 & -6 \\
\hline
\end{tabular}

${ }^{1}$ Business cycle chronologies are taken from http://www.nber.org/; growth cycle chronologies are taken from Zarnowitz and Ozyildirim (2002). Key: $\mathrm{P}=$ peak; $\mathrm{T}=$ trough .

February 1988, index growth stagnated, but surged in December 1988, followed by a period of steady decline. Following the Bry-Boschan censoring rule of identifying real peaks, we regard December 1988 as a temporary disturbance. The transportation sector started to recover in July 1989, but its growth was interrupted in August 1990, which is one month after the beginning of the economic recession. The Index started to move up at about the same time as the economic recovery after March 1991.

The Total Transportation Output Index clearly peaked 16 months prior to the beginning of the latest recession. It appears that the Index started to move up in June 2001, but the events of September 11 have distorted the data. September 2001 also marks the lowest point in aggregate transportation activity since its last peak in November 1999 and is roughly coincident with the recently announced trough of November 2001 for the latest economic recession. The Index has been recovering since then, albeit with interruptions.

Overall, the Transportation Output Index led the three peaks with a considerable lead time (median 16 months); ${ }^{11}$ the signals for recovery were almost con-

11 Between 1953 and 1982, the average lead time of the composite index of 11 leading indicators relative to the NBER-defined reference cycles is 9.7 months at peaks and 4.6 months at troughs (see table 11.4 in Zarnowitz 1992). temporaneous. The index would have given two false signals for economic recession in August 1984 and December 1994. However, they were not false in the sense that these peaks were followed by recessions in the growth cycle. Hence, the strong cyclical changes in transportation output appear to be more synchronized with growth slowdowns rather than fullfledged recessions of the U.S. economy. This also suggests that the cyclical movement in these indexes foreshadows the growth cycles of the economy more consistently than the business cycles. Thus, the newly constructed Transportation Output Index can be very useful in monitoring the fluctuations in general economic activity from the perspective of transportation.

When we look at the freight and passenger transportation indexes separately in figures $3 b$ and $3 c$, we find that the cyclical movements in the Total Transportation Output Index are mostly determined by freight movement. The freight index reached its peak and trough during the same months as the total index during the July 1981November 1982 recession. The passenger index, on the other hand, did not have the corresponding cyclical movement during this period. Freight activities dominated the transportation sector in the early 1980s.

During the economic recession of July 1990March 1991, the freight index peak occurred two months before that of the total index, while the pas- 
senger index started to decline in September 1990, which is one month after the peak of the economy. A similar phenomenon occurred during the latest recession. The freight index peak occurred at about the same time as the total index, but with a much deeper amplitude. The passenger index reached its peak 12 months later. Furthermore, September 11 had a more profound impact on passenger transportation than on freight transportation. As a result, the total index mimics the movement in the passenger index more closely during this recessionary episode than on previous occasions.

The sequence of peaks and troughs in these indexes and their relationship to business cycles in the economy may reflect some interesting underlying linkages. Freight movement adjusts early to the demand or supply shocks in the economy; these adjustments or fluctuations across different sectors can eventually lead to a full-fledged recession or be limited to sectoral cycles. On the other hand, passenger transportation activities are affected when the state of the overall economy has changed due to demand shocks, especially in a recession. The last two recessions seem to follow this stylized scenario. Because every recession is caused by a mixture of different demand and supply factors, the relative changes in the passenger and freight indexes may not always follow the above sequence. Overall, turning points in the total index stay between those of its two components, but tend to be closer to those of the freight index.

\section{Growth Cycles}

In a growth cycle, the economy undergoes alternating periods of deceleration and acceleration that may not develop into a full-fledged recession (see Zarnowitz 1992, chapters 7 and 8; and Zarnowitz and Ozyildirim 2002). Growth cycles are less well known compared with classic business cycles, and they usually cover both full-fledged business cycles and growth slowdowns. Technically, the growth cycle refers to the cyclical component of a typical time series, which is the deviation of a seasonally adjusted series from its estimated trend. Over our sample period, there were six such episodes in the overall economy, four of which included the recessions of the period. They are all clearly discernable with major downswings in the Total Transportation Output Index in figures 3a to 3c.

Depending on the method of estimation of the trend from a time series, growth cycles could differ. The conventional NBER algorithm to estimate the secular trend and identify the growth cycles is the Phase Average Trend (PAT) method (Boschan and Ebanks 1978). The PAT starts by determining preliminary turning points based on the deviation from a 75-month moving average (first approximation) of a deseasonalized time series. Then, values at the turning points are averaged to obtain phase averages (each phase is defined on two turning points). The three-item moving averages of these phase averages are subsequently computed to obtain the so-called "triplets." The midpoints of the triplets are connected, and the connected level series is further adjusted to match the level of the original series. Then a 12-month moving average (second approximation) of the adjusted series yields the estimated secular trend. $^{12}$

Using the estimated trend, the NBER growth cycles are defined based on the deviation of the deseasonalized series from the PAT. We then compare the growth cycles of the Transportation Output Index obtained using the PAT with the NBER growth cycle chronology. The growth cycles of the

12 Since the calculation of the PAT can be tedious, a good alternative would be the use of the H-P filter (Hodrick and Prescott 1997). The H-P filter chooses the trend value $s_{t}$ of the deseasonalized data $y_{t}$ to minimize

$$
\sum_{t=1}^{T}\left(y_{t}-s_{t}\right)^{2}+\lambda \sum_{t=2}^{T-1}\left(\left(s_{t+1}-s_{t}\right)-\left(s_{t}-s_{t-1}\right)\right)^{2}
$$

The penalty $\lambda$ parameter controls the smoothness of the series. The larger the value of $\lambda$ is, the smoother the trend. Currently, the H-P filter can be implemented using most econometric software (e.g., EViews).

Zarnowitz and Ozyildirim (2002) point out that the selection of the trend is inevitably associated with considerable arbitrariness, which has long been a source of confusion in the literature of growth cycles. However, they found that estimated trends are generally similar for the PAT and the H-P filter when the value of $\lambda$ is around 108,000 for monthly data, and the PAT is superior to its alternatives in the matter of details. Consistent with their finding, with the value of $\lambda=108,000$, the two estimated trends based on the PAT and the H-P filter were very similar, as depicted in figure 4. By its very nature, however, the PAT attributes a somewhat bigger part of the cyclical movements to trend. 
FIGURE 4 Trends in the Transportation Output Index

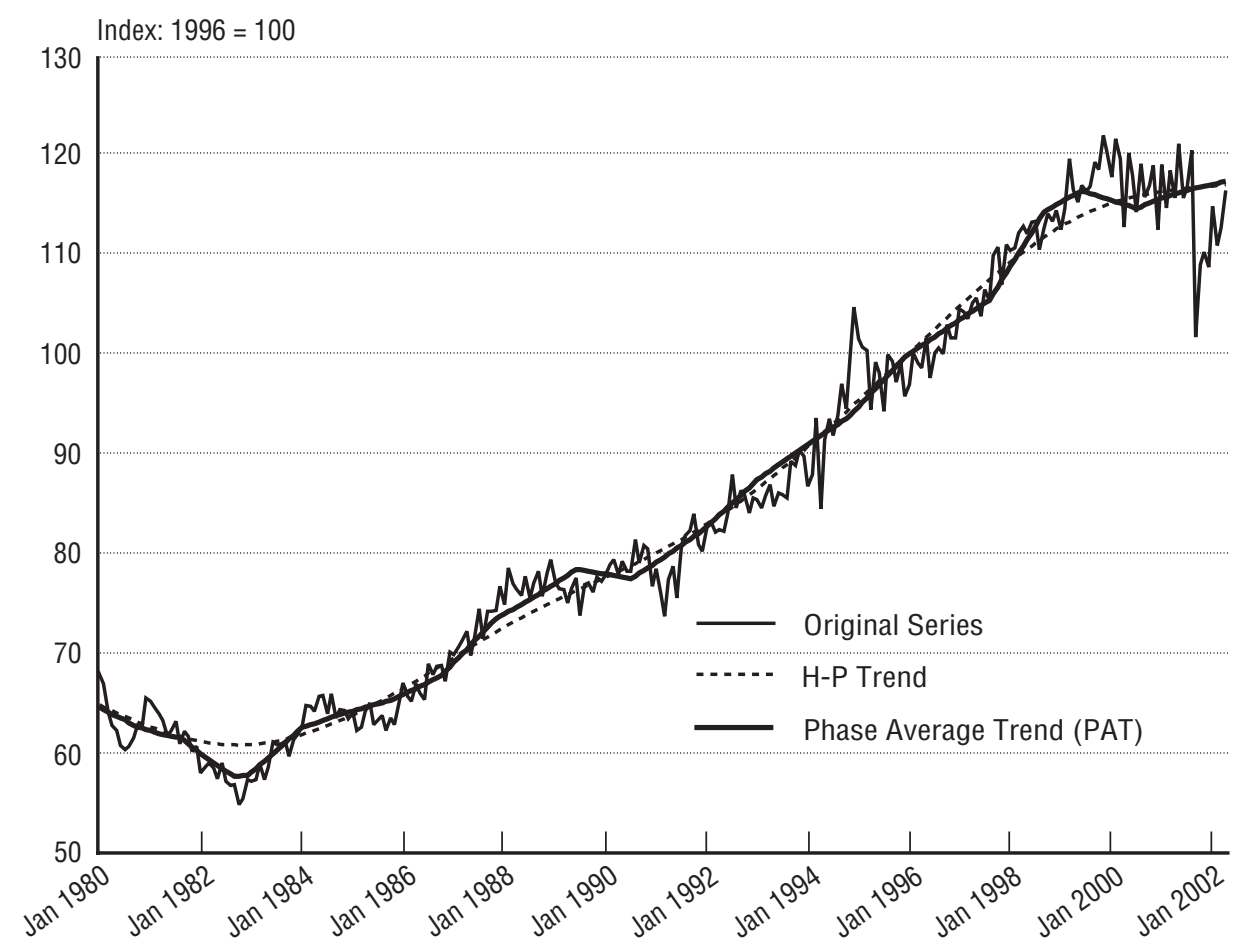

Transportation Output Index together with its smoothed version are compared with the NBERdefined growth cycles for the overall economy in figure 5. The smoothing was done using a filter developed by Statistics Canada (Hertzberg and Beckman 1989). We found that the Total Transportation Output Index led the growth cycle consistently with average lead times of six months at peaks and five months at troughs. Only for the economic slowdown of January 1995-January 1996 was the Transportation Output Index roughly coincident both at the peak and the trough. Figure 5 also reveals slowdowns in the transportation sector from July 1992-August 1993 (mainly due to a sharp decline in air passenger travel at that time) and October 1997-August 1998 (a short and shallow slowdown compared with others), which were not followed by corresponding slowdowns in the overall economy. Except for these caveats, our Transportation Output Index gave correct signals for all economy-wide slowdowns of the period. A look at the freight and passenger indexes suggests that the classic business and growth cycle characteristics of transportation output are mainly due to the freight component, and the passenger component does not show a consistent lead-lag relationship with reference to the economic cycle.
We should, however, point out that the lead time analysis presented above does not take into account either the lag involved in obtaining the data necessary to construct the series or the necessity of employing a filter rule that by its very nature involves a delay in identifying changes. It is necessary to develop some filter rule (e.g., a three consecutive decline rule for signaling a downturn) that would enable analysts, in real time, to distinguish between the irregular movements and the true signals of cyclical turns. ${ }^{13}$ After all, a leading indicator is only as good as the filter rule that interprets its movements. These rules typically involve tradeoffs of accuracy for timeliness and missed signals for false alarms, see Lahiri and Wang (1994). We have so far identified the peaks and troughs of the indexes from an ex post perspective. Further analysis is needed to establish the ex ante predictive ability of the Transportation Output Index. In future research, we plan to develop filter rules that would enable us, in real time, to distinguish between the irregular movements and the true signals of cyclical turns.

${ }^{13}$ For a discussion of alternative rules for forecasting the cyclical movements of the Composite Index of Leading Indicators for the economy, see Stekler (1991, pp. 169181). 
FIGURE 5 Growth Cycles in the Transportation Output Index

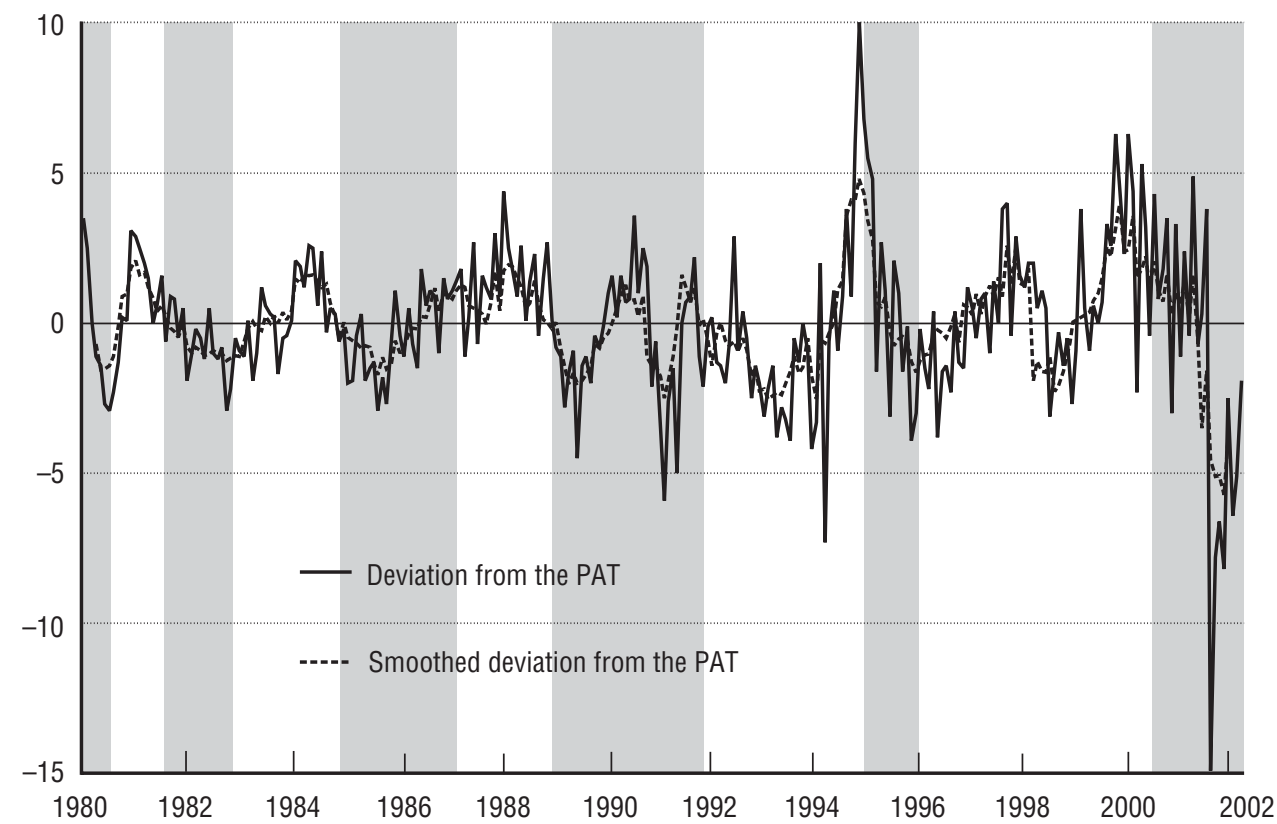

Note: Shaded areas represent the NBER-defined growth slowdown in the U.S. economy (the trough for the latest growth slowdown has not been determined).

\section{COMPARISON WITH ALTERNATIVE OUTPUT MEASURES}

It is also possible to compare our Total Transportation Output Index with annual data produced by BEA and BLS on the gross output of the transportation sector. Gordon (1992) and, more recently, Bosworth (2001) and Yuskavage (2001) have provided valuable insights into the different methodologies and data that BEA and BLS use to construct the output. The Office of Productivity and Technology of BLS maintains an annual series on transportation output that begins at 1987.

Gullickson and Harper (2002) present an analysis using experimental BLS output data based on a multifactor economic growth model that goes back to 1947. Since BEA went through a major overhaul in generating gross output data in the 1980s, and after 1991 it switched to using BLS's Producer Price Index to compute the price deflator, we plotted the BEA series obtained from the Survey of Current Business (November 1997) only after 1991.

Figure 6 shows that even though the four transportation output series are derived using widely different approaches, remarkably similar trends are exhibited (values of all series were normalized at $1996=100)$. The average values of the four series are also very similar. The BEA series, which has more comprehensive coverage and is benchmarked to the five-year economic census, followed our Transportation Output Index closely throughout the 1990s, whereas the BLS series seems to have slowed down since 1998. More importantly, it appears that while the three alternative annual output measures reflect the long-term trends, our monthly transportation output measure is superior to them in reflecting cyclical movements in this sector. In figure 6, our Transportation Output Index deviates temporarily from the other three series whenever there are recessions and growth slowdowns in the economy.

Following Gordon (1992) and Bosworth (2001), in table 3, we present alternative estimates of output growth in the transportation sector and in its three major subsectors-trucking, railroads, and airlines-between 1980 and 2000. For this comparison, we did not include the BLS real output series because it is available only after 1987 and it is very similar to the BLS experimental series. The growth rates are also reported separately for 1980-1991 and 1992-2000. In computing these rates, we converted our monthly values to annual figures. For the total output, the growth rates of our index fall between the BEA and BLS rates in all periods. The same is true for trucking except that our index has a 


\section{FIGURE 6 Comparison of Monthly Transportation Index with Annual BEA and BLS Outputs}

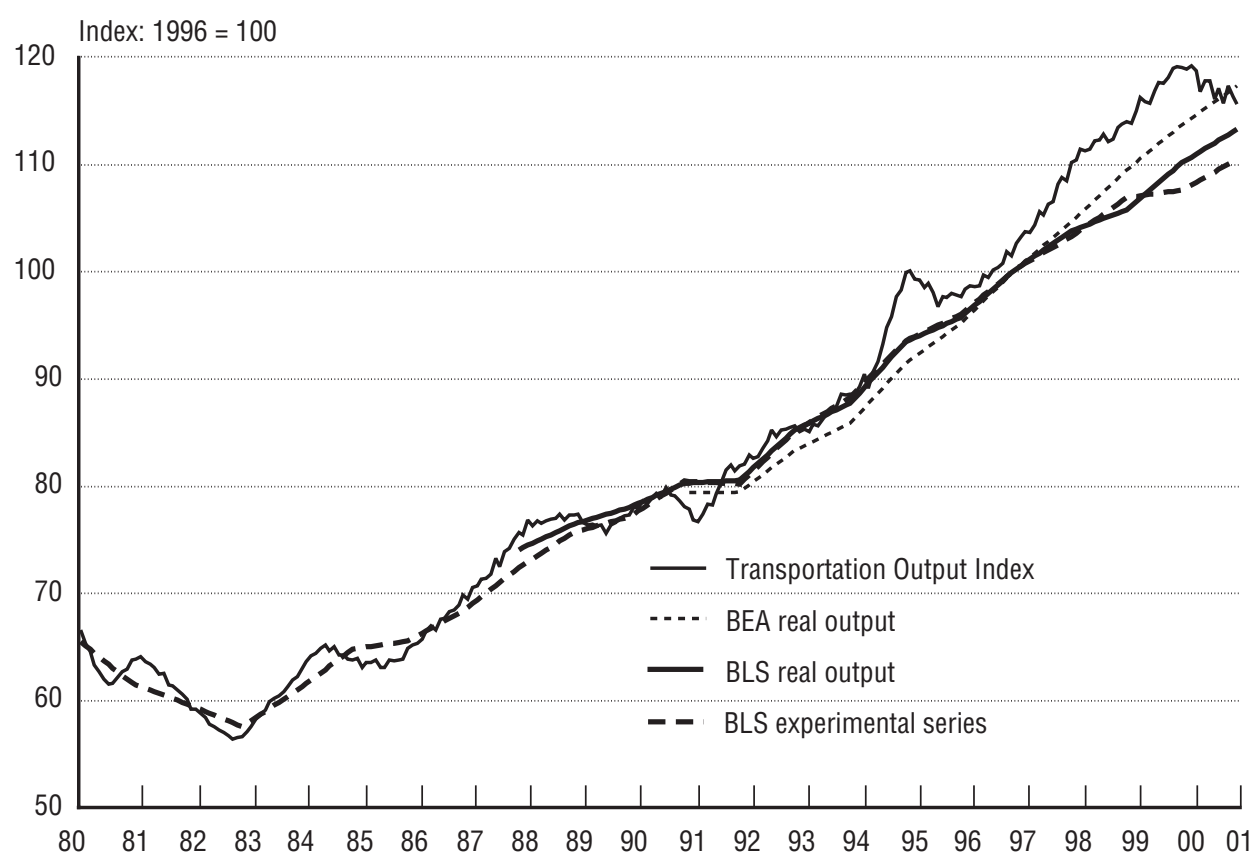

higher growth rate than both BEA and BLS during 1992-2000. For railroads, our index has higher rates of growth than that of BEA and BLS for the overall period and in the 1990s. However, during 1980-1991, the rail growth rate of our index was between the BEA and BLS values. For airlines, our index is almost the same as that of the BLS index, whereas the BEA figures are somewhat higher.

Interestingly, we found that our monthly index has a lot more cyclical variation than the other three series. This is not surprising in view of the fact that the BEA and BLS values are annual and are benchmarked to five-year economic surveys. Given that we constructed the Total Transportation Output Index using monthly data on a series of eight related factors, most of which were not previously used, it is heartening to note the level of agreement in the three series. The advantage of our approach, however, is that the index can be made available on a monthly basis such that the health of the transportation sector can be monitored in real time.

\section{CONCLUSIONS}

In this paper, we developed a monthly output index of the U.S. transportation sector for January 1980 through April 2002, covering air, rail, water, truck, transit, and pipeline activities. The included indus- tries cover from $89.7 \%$ to $93.9 \%$ of the total forhire transportation GDP during 1980 to 2000 . We use both linked Laspeyres and Fisher Ideal Index methods to construct the indexes. These two series were found to be very similar. Separate indexes for freight and passenger transportation were also constructed, and freight was found to be the dominant component in the Total Transportation Output Index. The index closely follows the annual transportation output figures produced by BLS and BEA, even though our monthly index displays more pronounced cyclical movements. Thus, our approach to measuring output in the transportation sector can be useful for measuring productivity in the sector and can be extended to other nonmanufacturing sectors as well.

We also examined the characteristics of the transportation output measure in relation to the classical business and growth cycles of the overall economy. The transportation output cycles are studied using the Phase Average Trend and Hodrick-Prescott filter. The strong cyclical movements in transportation output appear to be more synchronized with the growth slowdowns rather than the full-fledged recessions of the U.S. economy. Based on the cycles generated from the PAT, we found that the index led the NBER-defined growth cycles with an average lead time of six months at peaks and five months at 
TABLE 3 Comparisons of Alternative Measures of Output Growth in the

Transportation Sector

Compound annual rate

\begin{tabular}{lc|cc} 
Output measures & $\mathbf{1 9 8 0 - 2 0 0 0}$ & $\mathbf{1 9 8 0 - 1 9 9 1}$ & $\mathbf{1 9 9 2 - 2 0 0 0}$ \\
\hline Trucking & & & \\
BEA real output & $4.8 \%$ & $4.8 \%$ & $3.9 \%$ \\
BLS experimental real output & $2.3 \%$ & $1.3 \%$ & $2.8 \%$ \\
Transportation Output Index & $3.4 \%$ & $1.7 \%$ & $4.5 \%$ \\
Railroads & & & \\
BEA real output & $1.8 \%$ & $1.5 \%$ & $1.7 \%$ \\
BLS experimental real output & $1.8 \%$ & $0.8 \%$ & $2.6 \%$ \\
Transportation Output Index & $2.2 \%$ & $1.0 \%$ & $3.3 \%$ \\
Airlines & & & \\
BEA real output & $5.4 \%$ & $5.7 \%$ & $4.6 \%$ \\
BLS experimental real output & $5.0 \%$ & $4.9 \%$ & $4.4 \%$ \\
Transportation Output Index & $5.0 \%$ & $4.9 \%$ & $4.4 \%$ \\
Total & & & \\
BEA real output & $4.2 \%$ & $4.1 \%$ & $3.9 \%$ \\
BLS experimental real output & $2.3 \%$ & $1.3 \%$ & $2.8 \%$ \\
Transportation Output Index & $3.0 \%$ & $1.9 \%$ & $3.7 \%$ \\
\hline
\end{tabular}

Sources: BEA output data are from U.S. Department of Commerce, Bureau of Economic Analysis, "Gross Output by Detailed Industry," table. See Gullickson and Harper (2002) for the BLS experimental output series.

troughs with almost no false signals. Admittedly, the lead-lag analysis reported here is retrospective. In future research, we would like to develop ex ante filter rules that would enable us, in real time, to distinguish between true cyclical turns and irregular movements of the transportation series. Further analysis is needed to establish the ex ante predictive value of the Transportation Output Index.

While we believe the Total Transportation Output Index yields a valid measure of output in the industry, we recognize there are some data problems and that refinements in the indexes may be necessary to improve it in the future. First, this index only measures output in the services sector of the industry. The activity involved in the production of transportation equipment is not included, nor is the activity involved in the construction of transportation infrastructure.

Second, within the services sector only for-hire transportation is included. The activity involved in intrafirm (in-house) and household transportation (HPTS) has been excluded. To the extent that forhire and these two transportation activities display different trends, the current index will not yield a precise picture of economic activity in the industry. Han and Fang (2000) estimated that in-house and for-hire components of total transportation activity constituted nearly $1.97 \%$ and $3.16 \%$, respectively, of total GDP in 1997. Furthermore, Chen et al. (2003) estimated the magnitude of HPTS to be about 1.9 times that of all for-hire transportation industries between 1991 and 2000. Inclusion of both in-house and HPTS components would increase the contribution of transportation services to the total GDP from $3.16 \%$ to $11.0 \%$, if based on TSA 1997 data. In the future, it will be useful to incorporate these two components as part of our Transportation Output Index once monthly data are available. In addition, the index excludes activity in some of the minor for-hire subsectors like scenic and sightseeing, support activities, postal service, and couriers and messengers.

Third, the waterborne component of the index only includes internal waterway traffic. It does not include deep seas, Great Lakes, coastal trade, or cruise travel. Again, if the trends in the excluded items differ from the data included, the results would be imprecise. Monthly data on some of these excluded items are currently being developed by the U.S. Army Corps of Engineers and can be easily integrated in our analysis as soon as they are available. 
Finally, monthly data on national transit ridership are available on a quarterly basis and lag by four months. Other monthly data are sometimes available with a lag of one to three months. For the purpose of releasing the output index with a usual lag of one to two months, some of the latest monthly data must be forecasted on a provisional basis using methods discussed in McGuckin et al. (2001). Fortunately, however, the major components of the series (trucking, air, and rail freight) are available quickly, and hence monthly figures for the total transportation sector can be reported soon after release with confidence.

Despite these caveats and suggestions for refining the indexes, as presently constructed they can provide sufficiently accurate estimates of the level of economic activity in the transportation sector.

\section{ACKNOWLEDGMENTS}

We thank the following individuals for numerous insightful discussions and help in identifying relevant data sources: Mazhar Ali Awan, Terry Branson, David Chesser, Clyde Crimmel, Bob Costello, Christie Dawson, Stan Ellis, Robert Finkelstein, Robert Ganz, Bill Gullickson, Frank Hardesty, William Jeffers, Paul Kern, Brian Moyer, Sandia Porter, Paul Posey, Jeff Potter, Brian Sloboda, Miranda Stuart, Thea Thomas, Sharon Trench, and Jay Wieriman.

This study was supported by a grant from the Bureau of Transportation Statistics (BTS), U.S. Department of Transportation, and benefited from the comments from BTS staff and many others, including Anirvan Banerji, Bill Bannister, Charlie Han, Rick Kowalewski, Ashish Sen, Jack Wells, and Victor Zarnowitz. This paper also benefited from the insightful comments of three anonymous referees and the Editor-in-Chief of the journal.

The contents of this paper reflect the views of the authors and not necessarily those of the Bureau of Transportation Statistics.

\section{REFERENCES}

Boschan, C. and W.W. Ebanks. 1978. The Phase-Average Trend: A New Way of Measuring Economic Growth. 1978 Proceedings of the Business and Economic Statistics Section. Washington, DC: American Statistical Association.
Bosworth, B. 2001. Output and Productivity in the Transportation Sector: An Overview. The Brookings Institution.

Bry, G. and C. Boschan. 1971. Cyclical Analysis of Time Series: Selected Procedures and Computer Programs, NBER Technical Paper 20. National Bureau of Economic Research.

Chen, D., B. Fang, X. Han, and B. Sloboda. 2003. Household Production of Transportation Services Through Automobiles: An Expansion of the Transportation Satellite Accounts. U.S. Department of Transportation, Bureau of Transportation Statistics, draft.

Corrado, C., C. Gilbert, and R. Raddock. 1997. Industrial Production and Capacity Utilization: Historical Revision and Recent Developments. Federal Reserve Bulletin. February.

Fang, B., X. Han, A.M. Lawson, and S.K.S. Lum. 1998. U.S. Transportation Satellite Accounts for 1992. Survey of Current Business 78(4), April.

Fang, B., X. Han, S. Okubo, and A.M. Lawson. 2000. U.S. Transportation Satellite Accounts for 1996. Survey of Current Business 80(5), May.

Ghosh, A.R. and H.C. Wolf. 1997. Geographical and Sectoral Shocks in the U.S. Business Cycle, NBER Working Paper \#6180. National Bureau of Economic Research. September.

Gordon, R.J. 1992. Productivity in the Transportation Sector. Output Measurement in the Service Sectors. Edited by Z. Griliches. Chicago, IL: University of Chicago Press. pp. 371428.

Gullickson, W. and M.J. Harper. 2002. Bias in Aggregate Productivity Trends Revisited. Monthly Labor Review 125(3), March.

Han, X. and B. Fang. 2000. Four Measures of Transportation's Economic Importance. Journal of Transportation and Statistics $3(1): 15-30$.

Hertzberg, M.P. and B.A. Beckman. 1989. Business Cycle Indicators: Revised Composite Indexes. Business Conditions Digest 29(1), January.

Hodrick, R.J. and E.C. Prescott. 1997. Postwar U.S. Business Cycles: An Empirical Investigation. Journal of Money, Credit, and Banking 29(1):1-16.

Lahiri, K. and J. Wang. 1994. Predicting Cyclical Turning Points with Leading Index in a Markov Switching Model. Journal of Forecasting 13:245-263.

Landefeld, J.S. and R.P. Parker. 1995. Preview of the Comprehensive Revision of the National Income and Product Accounts: BEA's New Featured Measures of Output and Prices. Survey of Current Business, July.

Layton, A. and G.H. Moore. 1989. Leading Indicators for the Service Sector. Journal of Business and Economic Statistics $7(3): 379-386$.

McGuckin, R.H., A. Ozyildirim, and V. Zarnowitz. 2001. Composite Index of Leading Economic Indicators: How to Make It More Timely, NBER Working paper \#8430. National Bureau of Economic Research. 
Shiskin, J., A.H. Young, and J.C. Musgrave. 1967. The X-11 Variant of the Census Method II Seasonal Adjustment Program, Technical Paper 15. U.S. Department of Commerce, Bureau of the Census.

Stekler, H.O. 1991. Forecasting Cyclical Turning Points. Leading Economic Indicators: New Approaches and Forecasting Records. Edited by K. Lahiri and G.H. Moore. Cambridge, England: Cambridge University Press.

Yuskavage, R.E. 2001. Issues in the Measurement of Transportation Output: The Perspective of the BEA Industry Accounts, Brookings Workshop. May.

Zarnowitz, V. 1992. Business Cycles: Theory, History, Indicators, and Forecasting. Chicago, IL: University of Chicago Press.

Zarnowitz, V. and A. Ozyildirim. 2002. Time Series Decomposition and Measurement of Business Cycles, Trends and
Growth Cycles, NBER Working Paper \#8736. National Bureau of Economic Research.

Authors' Addresses: Corresponding Author: Kajal Lahiri, Economics Department, University at Albany, SUNY, Albany, NY 12222. Email: klahiri@albany.edu.

Herman Stekler, Department of Economics, George Washington University, 2201 G Street, NW, Washington, DC 20052. Email: hstekler@gwu.edu.

Wenxiong Yao, Economics Department, University at Albany, SUNY, Albany, NY 12222.

Email:wy7098@albany.edu.

Peg Young, Bureau of Transportation Statistics, U.S. Department of Transportation, 400 Seventh St., SW, Room 3430, Washington, DC 20590. Email: peg.young@bts.gov. 


\section{Appendix 1 \\ Documentation of the Data Series}

\section{Air Revenue Passenger-Miles (RPM)}

\begin{tabular}{|l|l|}
\hline Name of series & Air Revenue Passenger-Miles (RPM) \\
\hline Explanation & One revenue passenger transported one mile \\
\hline Source & $\begin{array}{l}\text { U.S. Department of Transportation, Bureau of Transportation Statistics, } \\
\text { Office of Airline Information, Air Carrier Traffic Statistics Monthly, } \\
\text { available at http://www.bts.gov/oai, January 1992 }\end{array}$ \\
\hline Data format & Preliminary data; seasonally adjusted (in thousands) \\
\hline Publication date & Available at the end of the month for the 2 previous months \\
\hline Revisions & The latest 12 months of data are preliminary \\
\hline Comments & Based on BTS Form 41 filed by large certificated air carriers \\
\hline
\end{tabular}

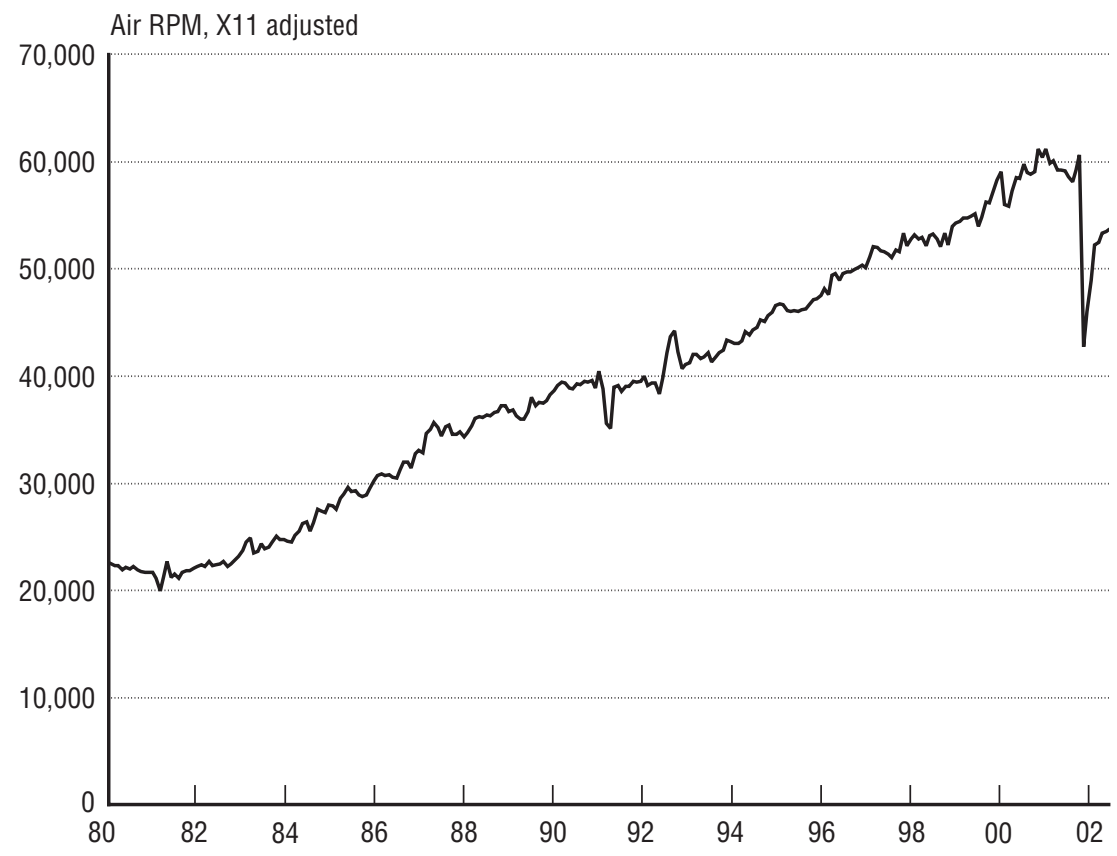




\section{National Transit Ridership}

\begin{tabular}{|l|l|}
\hline Name of series & National Transit Ridership \\
\hline Explanation & Estimated unlinked passenger trips \\
\hline Source & $\begin{array}{l}\text { American Public Transportation Association (APTA), APTA Quarterly } \\
\text { Transit Ridership Report, available at http://www.bts.gov since January } \\
1992\end{array}$ \\
\hline Data format & Preliminary data; seasonally adjusted (in thousands of riders) \\
\hline Publication date & Available in the first day of each quarter for the 2 previous quarters \\
\hline Revisions & The latest 3 years of data are preliminary \\
\hline Comments & Includes ridership of commuter rail, heavy rail, light rail, and others \\
\hline
\end{tabular}

Transit Ridership, X11 adjusted

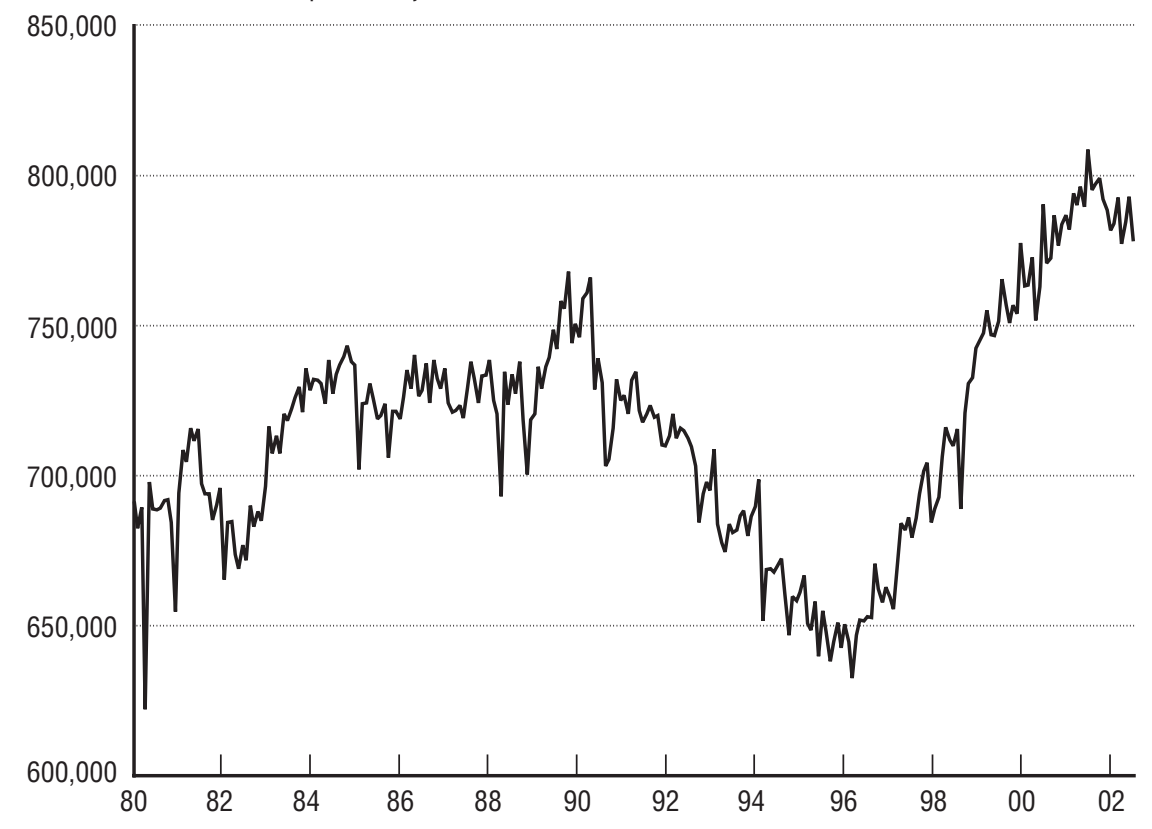




\section{Rail Revenue Passenger-Miles (RPM)}

\begin{tabular}{|c|c|}
\hline Name of series & Rail Revenue Passenger-Miles (RPM) \\
\hline Explanation & RPMs carried by Amtrak and Alaska Railroads \\
\hline Source & $\begin{array}{l}\text { U.S. Department of Transportation, Federal Railroad Administration } \\
\text { (FRA), Office of Safety Analysis, FRA Accident/Incident Bulletin, avail- } \\
\text { able at http://safetydata.fra.dot.gov/OfficeofSafety/Default.asp) }\end{array}$ \\
\hline Data format & Preliminary data; seasonally adjusted (in millions of riders) \\
\hline Publication date & Beginning of each month for previous 2 months \\
\hline Revisions & The latest 12 months of data are preliminary \\
\hline Comments & $\begin{array}{l}\text { RPM for January } 1980-\text { December } 1985 \text { were estimated from data of } \\
\text { revenue passengers, because empty trains were counted into RPM } \\
\text { before that time }\end{array}$ \\
\hline
\end{tabular}

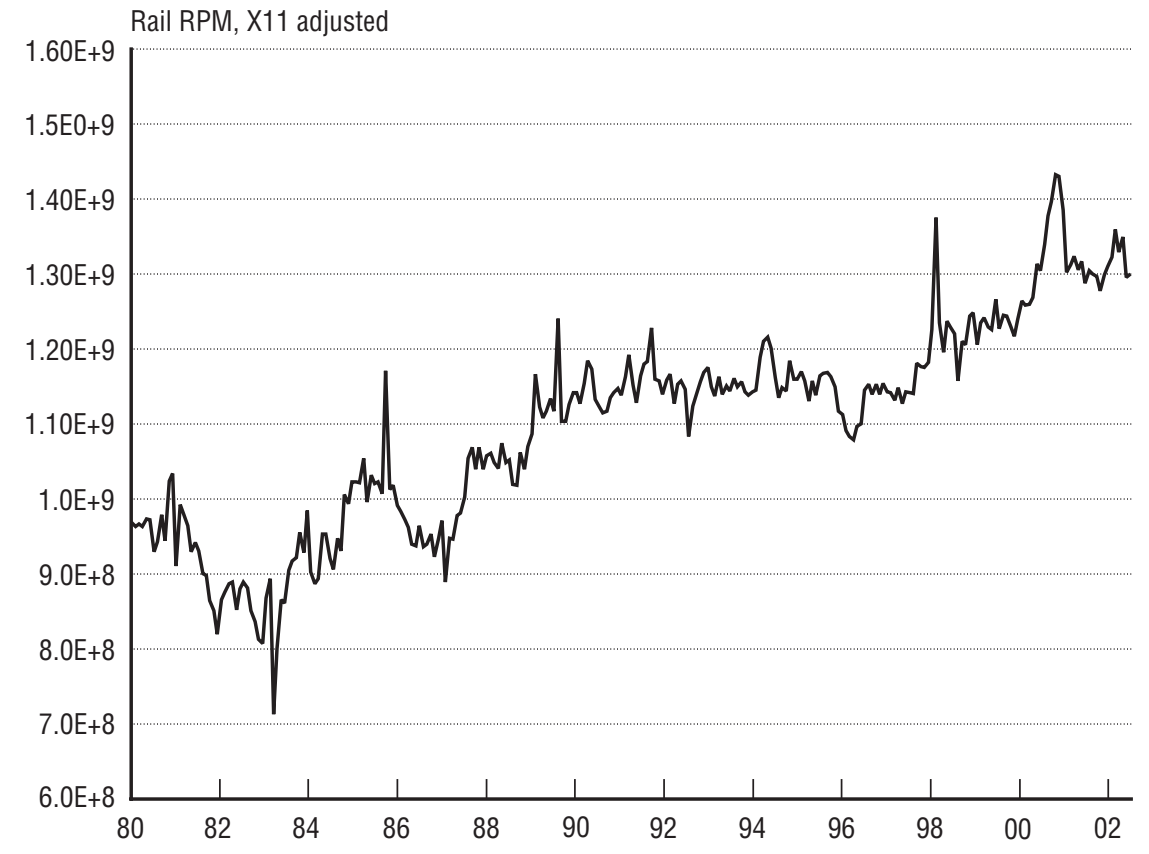




\section{Trucking Tonnage Index (TTI)}

\begin{tabular}{|l|l|}
\hline Name of series & Trucking Tonnage Index (TTI) \\
\hline Explanation & Truck loads \\
\hline Source & American Trucking Association (ATA), Monthly Trucking Report \\
\hline Data format & Index: $1996=100 ;$ monthly, seasonally adjusted and unadjusted \\
\hline Publication date & 3rd of each month for the previous 2 months \\
\hline Revisions & The latest monthly data are preliminary \\
\hline Comments & Estimated from tonnage reported by ATA's members in 50 states \\
\hline
\end{tabular}

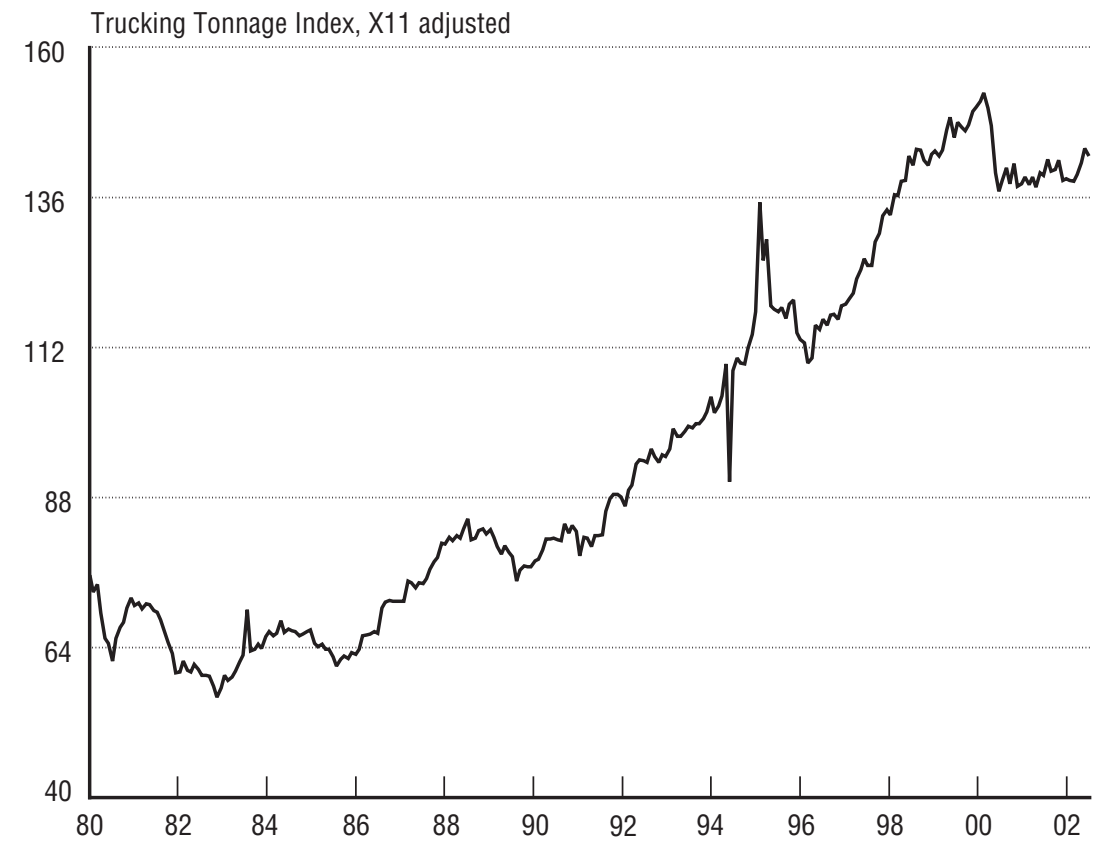




\section{Railroads Revenue Ton-Miles of Freight (RTMF)}

\begin{tabular}{|l|l|}
\hline Name of series & Railroads Revenue Ton-Miles of Freight (RTMF) \\
\hline Explanation & $\begin{array}{l}\text { Carloads of } 20 \text { railroads (total containers and trailers) in the United } \\
\text { States }\end{array}$ \\
\hline Source & $\begin{array}{l}\text { Association of American Railroads, Weekly Railroad Traffic, avail- } \\
\text { able at http://www.bts.gov since the 1st week of 1996 }\end{array}$ \\
\hline Data format & Preliminary data; quarterly; seasonally adjusted (in billions) \\
\hline Publication date & Second month of each quarter for the 2 previous quarters \\
\hline Revisions & The latest 12 months of data are preliminary \\
\hline Comments & $\begin{array}{l}\text { Monthly data were not available. We interpolated from the quarterly } \\
\text { data; however, we expect to work with the monthly series soon. }\end{array}$ \\
\hline
\end{tabular}

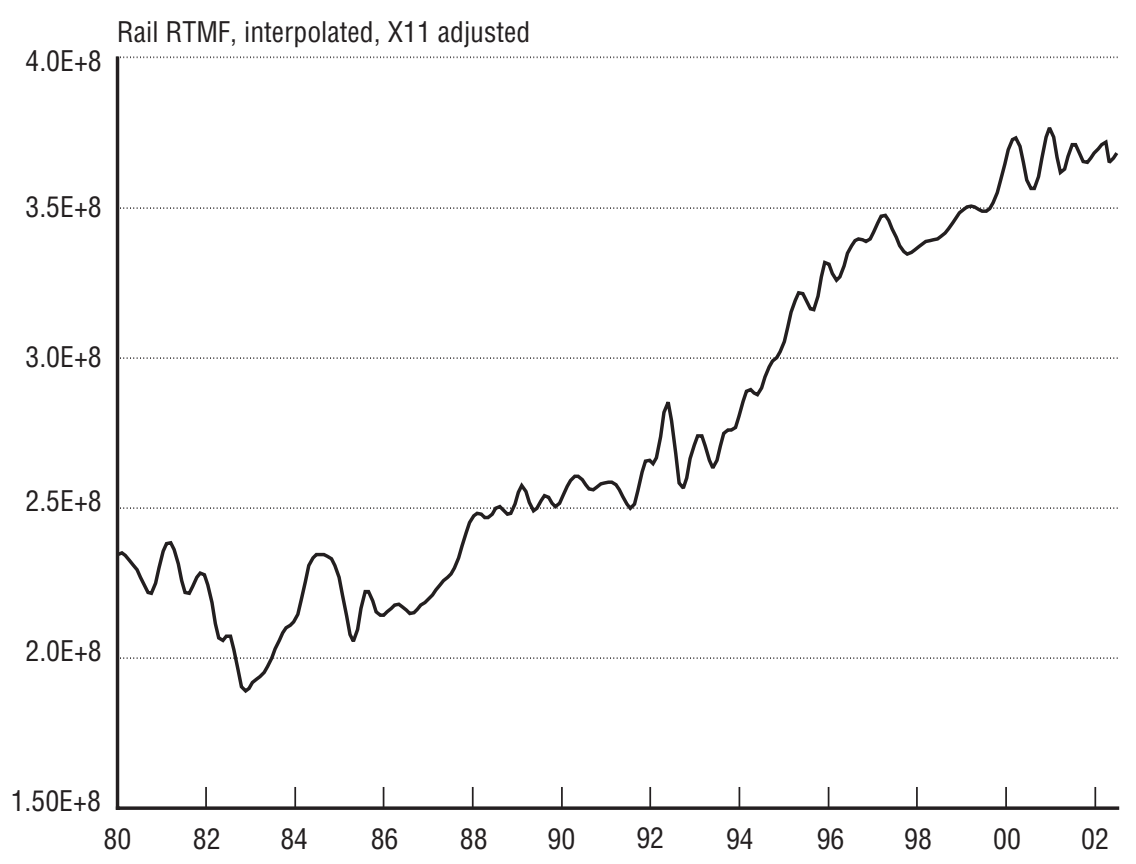




\section{Total Internal Commerce Tonnage Indicator (TICTI)}

\begin{tabular}{|l|l|}
\hline Name of series & Total Internal Commerce Tonnage Indicator (TICTI), all commodities \\
\hline Explanation & $\begin{array}{l}\text { Internal waterway tonnage of coal, petroleum and chemicals, and food } \\
\text { and farm products; estimated from 11 key locks on 9 rivers }\end{array}$ \\
\hline Source & $\begin{array}{l}\text { U.S. Army Corps of Engineers, Waterborne Commerce Statistics Center, } \\
\text { available at http://www.iwr.usace.army.mil/ndc/monthlyindicators.htm, } \\
\text { since January 1994 }\end{array}$ \\
\hline Data format & Preliminary data; seasonally adjusted (in millions of short tons) \\
\hline Publication date & The beginning of each month for the 2 previous months \\
\hline Revisions & The latest 12 months of data are preliminary \\
\hline Comments & $\begin{array}{l}\text { The data do not include great lakes, coastal and deep-sea waterborne } \\
\text { traffic, which are currently not available }\end{array}$ \\
\hline
\end{tabular}

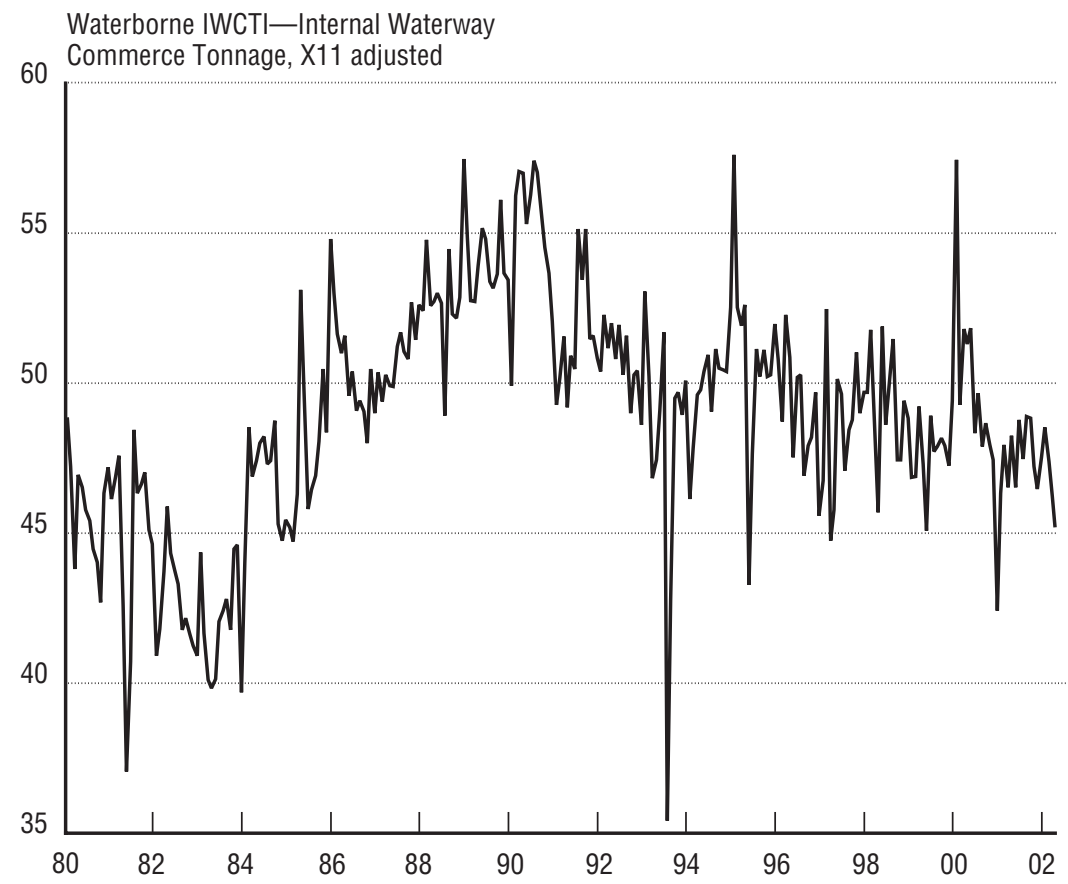




\section{Air Revenue Ton-Miles of Freight and Mails (RTMFM)}

\begin{tabular}{|l|l|}
\hline Name of series & Air Revenue Ton-Miles of Freight and Mail (RTMFM) \\
\hline Explanation & Ton-miles of freight and express mail transported by the air industry \\
\hline Source & $\begin{array}{l}\text { U.S. Department of Transportation, Bureau of Transportation Statis- } \\
\text { tics, Office of Airline Information, Air Carrier Traffic Statistics } \\
\text { Monthly, available at http://www.bts.gov/oai since January 1992 }\end{array}$ \\
\hline Data format & Preliminary data; seasonally adjusted (in thousands) \\
\hline Publication date & The end of the month for the 2 previous months \\
\hline Revisions & The latest 12 months of data are preliminary \\
\hline Comments & Based on BTS Form 41 filed by large certificated air carriers \\
\hline
\end{tabular}

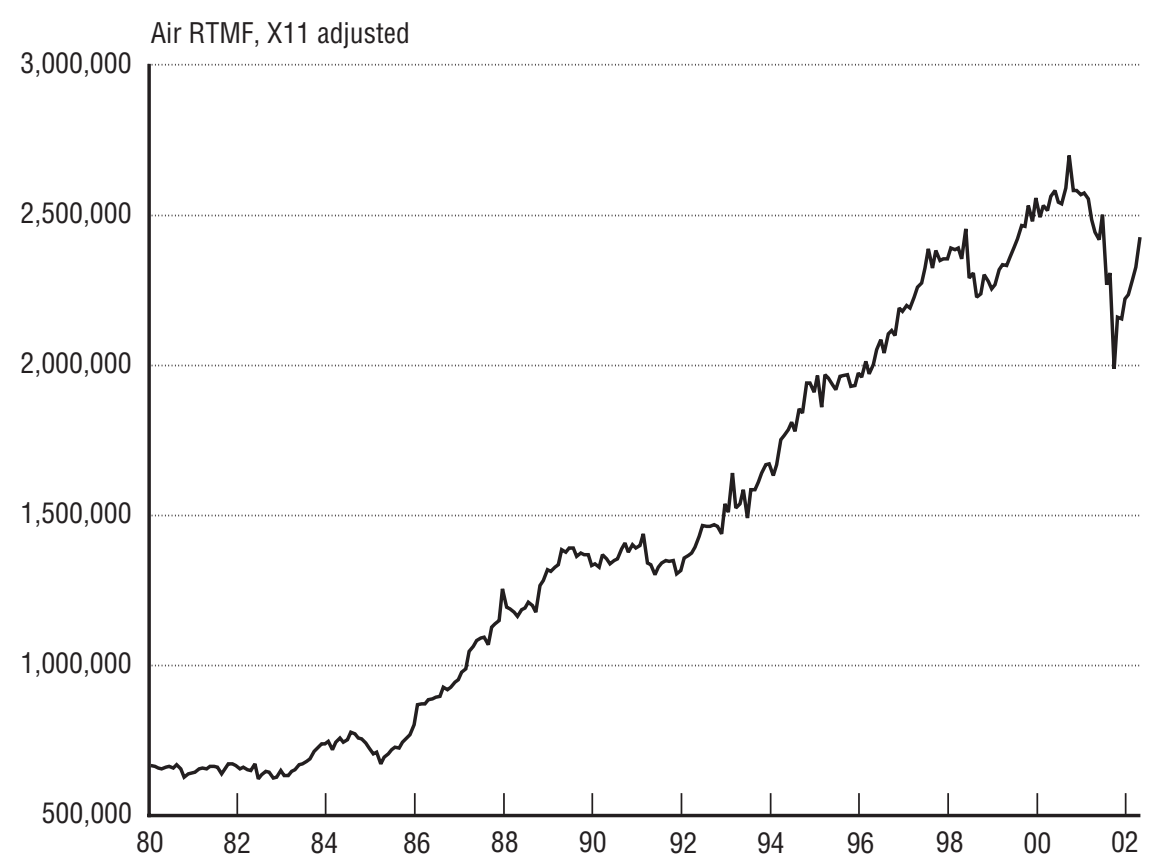


8. Index of Energy Movements by Pipeline (IEMP)

\begin{tabular}{|l|l|}
\hline Name of series & Index of Energy Movements by Pipeline (IEMP) \\
\hline Explanation & $\begin{array}{l}\text { Movements of crude oil and petroleum products between PADDs; } \\
\text { Alaska field production and consumption of natural gas }\end{array}$ \\
\hline Source & $\begin{array}{l}\text { U.S. Department of Energy, Energy Information Administration, } \\
\text { Petroleum Supply Monthly (for movements of crude oil and petroleum } \\
\text { products) and Monthly Energy Review (for natural gas and Alaska field } \\
\text { production) }\end{array}$ \\
\hline Data format & Final data; seasonally adjusted (in millions of tons) \\
\hline Publication date & 23rd-26th of each month for the 2 previous months \\
\hline Revisions & $\begin{array}{l}\text { No revision } \\
\text { Before January 1985, movements of crude oil between PADDs were not } \\
\text { included in the total. In constructing IEMP, crude oil and petroleum } \\
\text { products are in million barrels per day and natural gas is in cubic feet } \\
\text { and are converted into tons using conversion factors. Conversion fac- } \\
\text { tors: } 1 \text { cubic foot of natural gas = 1,020 Btu (heat unit); 1 million Btu = } \\
0.025 \text { tons of oil equivalent; 1 barrel of petroleum products = 5.326 } \\
\text { millions of Btu (heat unit). }\end{array}$ \\
\hline
\end{tabular}

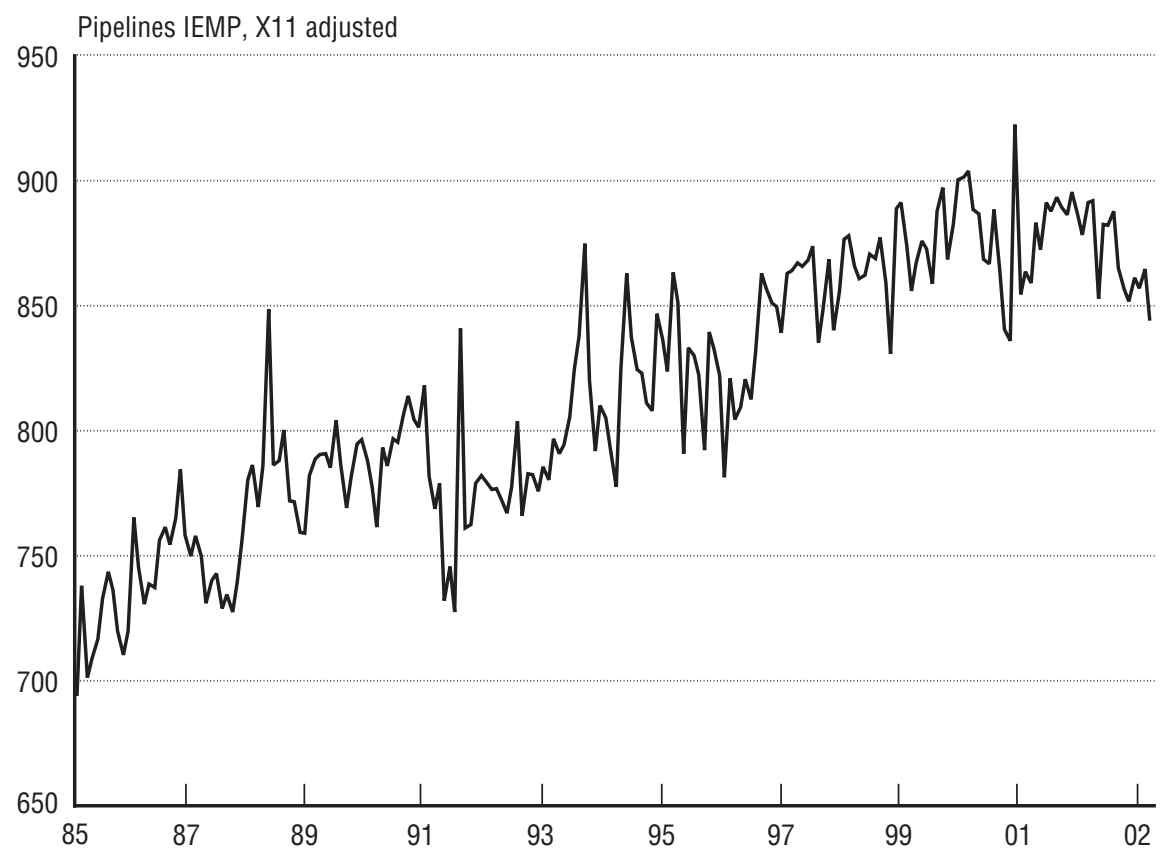




\section{Appendix 2}

\begin{tabular}{|c|c|c|c|c|c|c|c|}
\hline Time & $\begin{array}{l}\text { Total } \\
\text { Transportation } \\
\text { Index }\end{array}$ & $\begin{array}{l}\text { Freight } \\
\text { Transportation } \\
\text { Index }\end{array}$ & $\begin{array}{l}\text { Passenger } \\
\text { Transportation } \\
\text { Index }\end{array}$ & Time & $\begin{array}{c}\text { Total } \\
\text { Transportation } \\
\text { Index }\end{array}$ & $\begin{array}{c}\text { Freight } \\
\text { Transportation } \\
\text { Index }\end{array}$ & $\begin{array}{c}\text { Passenger } \\
\text { Transportation } \\
\text { Index }\end{array}$ \\
\hline Jan-80 & 68.2 & 70.9 & 58.9 & May-83 & 58.6 & 57.7 & 60.2 \\
\hline Feb-80 & 66.9 & 69.1 & 59.4 & Jun-83 & 61.1 & 60.2 & 62.5 \\
\hline Mar-80 & 64.1 & 65.8 & 57.7 & Jul-83 & 60.9 & 60.6 & 60.6 \\
\hline Apr-80 & 62.8 & 65.0 & 55.0 & Aug-83 & 61.0 & 60.2 & 62.0 \\
\hline May-80 & 62.3 & 63.7 & 57.0 & Sep-83 & 61.2 & 60.4 & 62.4 \\
\hline Jun-80 & 60.8 & 61.2 & 58.3 & Oct-83 & 59.7 & 58.4 & 62.0 \\
\hline Jul-80 & ${ }^{\mathrm{T}} 60.4$ & 60.9 & 57.7 & Nov-83 & 61.3 & 60.6 & 62.0 \\
\hline Aug-80 & 60.7 & 61.1 & 58.4 & Dec-83 & 61.8 & 61.1 & 62.7 \\
\hline Sep-80 & 61.5 & 62.7 & 57.1 & Jan-84 & 62.7 & 62.3 & 62.5 \\
\hline Oct-80 & 62.8 & 64.3 & 57.2 & Feb-84 & 64.8 & 64.6 & 64.0 \\
\hline Nov-80 & 62.6 & 64.8 & 54.9 & Mar-84 & 64.7 & 64.7 & 63.7 \\
\hline Dec-80 & $P_{65.5}$ & 68.2 & 56.5 & Apr-84 & 64.2 & 63.8 & 64.0 \\
\hline Jan-81 & 65.2 & 67.4 & 57.5 & May-84 & 65.7 & 65.4 & 65.1 \\
\hline Feb-81 & 64.6 & 67.0 & 56.3 & Jun-84 & 65.8 & 65.5 & 65.3 \\
\hline Mar-81 & 63.9 & 66.5 & 55.2 & Jul-84 & 64.0 & 63.6 & 63.8 \\
\hline Apr-81 & 63.3 & 64.9 & 57.2 & Aug-84 & $P_{66.0}$ & 65.4 & 66.3 \\
\hline May-81 & 61.7 & 62.5 & 58.0 & Sep-84 & 63.5 & 62.2 & 65.9 \\
\hline Jun-81 & 62.3 & 63.2 & 58.3 & Oct-84 & 64.4 & 63.0 & 66.7 \\
\hline Jul-81 & 63.2 & 64.7 & 57.4 & Nov-84 & 64.3 & 62.8 & 66.9 \\
\hline Aug-81 & 61.0 & 62.2 & 56.2 & Dec-84 & 63.5 & 61.8 & 66.6 \\
\hline Sep-81 & 62.2 & 63.5 & 57.2 & Jan-85 & 64.0 & 62.5 & 66.7 \\
\hline Oct-81 & 61.7 & 63.0 & 56.6 & Feb-85 & 62.3 & 60.4 & 66.1 \\
\hline Nov-81 & 60.2 & 61.3 & 55.8 & Mar-85 & 62.6 & 60.1 & 68.2 \\
\hline Dec-81 & 60.7 & 61.2 & 58.0 & Apr-85 & 64.2 & 61.7 & 69.8 \\
\hline Jan-82 & 58.0 & 58.1 & 56.8 & May-85 & 65.0 & 62.7 & 70.0 \\
\hline Feb-82 & 58.6 & 58.7 & 57.2 & Jun-85 & 62.9 & 60.4 & 68.4 \\
\hline Mar-82 & 59.1 & 59.0 & 57.9 & Jul-85 & 63.4 & 60.7 & 69.5 \\
\hline Apr-82 & 58.5 & 58.3 & 58.0 & Aug-85 & 63.7 & 61.0 & 69.9 \\
\hline May-82 & 57.5 & 57.5 & 56.1 & Sep-85 & ${ }^{\top} 62.3$ & 60.1 & 66.8 \\
\hline Jun-82 & 59.0 & 58.9 & 58.2 & Oct-85 & 63.5 & 61.2 & 68.4 \\
\hline Jul-82 & 57.2 & 56.7 & 57.4 & Nov-85 & 62.8 & 60.6 & 67.6 \\
\hline Aug-82 & 56.7 & 55.7 & 58.4 & Dec-85 & 65.1 & 62.5 & 71.0 \\
\hline Sep-82 & 56.9 & 56.2 & 57.6 & Jan-86 & 67.0 & 64.7 & 71.9 \\
\hline Oct-82 & $\mathrm{T}_{54.8}$ & 53.6 & 57.1 & Feb-86 & 65.7 & 63.2 & 71.3 \\
\hline Nov-82 & 55.5 & 54.3 & 57.5 & Mar-86 & 65.2 & 62.2 & 72.0 \\
\hline Dec-82 & 57.3 & 56.1 & 59.6 & Apr-86 & 67.0 & 64.6 & 72.2 \\
\hline Jan-83 & 57.2 & 55.5 & 60.6 & May-86 & 66.0 & 63.6 & 71.1 \\
\hline Feb-83 & 57.4 & 55.7 & 60.9 & Jun-86 & 65.4 & 62.9 & 70.8 \\
\hline Mar-83 & 58.9 & 57.1 & 62.9 & Jul-86 & 68.9 & 66.9 & 73.0 \\
\hline Apr-83 & 57.3 & 56.0 & 59.9 & Key: $P=$ & eak; $\mathrm{T}=$ trough & & \\
\hline
\end{tabular}




\begin{tabular}{|c|c|c|c|c|c|c|c|}
\hline \multicolumn{8}{|c|}{$\begin{array}{l}\text { Monthly Values of Transportation } \\
\text { Indexes (continued) }\end{array}$} \\
\hline Time & $\begin{array}{c}\text { Total } \\
\text { Transportation } \\
\text { Index }\end{array}$ & $\begin{array}{c}\text { Freight } \\
\text { Transportation } \\
\text { Index }\end{array}$ & $\begin{array}{c}\text { Passenger } \\
\text { Transportation } \\
\text { Index }\end{array}$ & Time & $\begin{array}{c}\text { Total } \\
\text { Transportation } \\
\text { Index }\end{array}$ & $\begin{array}{c}\text { Freight } \\
\text { Transportation } \\
\text { Index }\end{array}$ & $\begin{array}{c}\text { Passenger } \\
\text { Transportation } \\
\text { Index }\end{array}$ \\
\hline Aug-86 & 67.9 & 65.1 & 74.1 & Mar-90 & 79.4 & 76.6 & 84.9 \\
\hline Sep-86 & 68.6 & 66.7 & 72.7 & Apr-90 & 77.9 & 75.1 & 83.6 \\
\hline Oct-86 & 68.7 & 66.8 & 72.7 & May-90 & 79.2 & 77.1 & 83.4 \\
\hline Nov-86 & 67.2 & 64.8 & 72.4 & Jun-90 & 78.2 & 75.1 & 84.4 \\
\hline Dec-86 & 70.1 & 67.4 & 76.2 & Jul-90 & 78.2 & 75.5 & 83.8 \\
\hline Jan-87 & 69.9 & 67.6 & 74.6 & Aug-90 & 81.3 & 78.8 & 86.3 \\
\hline Feb-87 & 70.6 & 68.0 & 76.3 & Sep-90 & 79.0 & 75.8 & 85.5 \\
\hline Mar-87 & 71.3 & 68.5 & 77.5 & Oct-90 & 80.8 & 77.9 & 86.7 \\
\hline Apr-87 & 72.2 & 69.0 & 79.4 & Nov-90 & 80.4 & 77.6 & 86.3 \\
\hline May-87 & 69.7 & 66.6 & 77.0 & Dec-90 & 76.7 & 72.8 & 84.7 \\
\hline Jun-87 & 71.5 & 69.2 & 76.6 & Jan-91 & 78.5 & 75.8 & 83.9 \\
\hline Jul-87 & 74.4 & 72.1 & 79.2 & Feb-91 & 75.9 & 74.8 & 78.1 \\
\hline Aug-87 & 71.4 & 68.0 & 79.1 & Mar-91 & $\mathrm{T}_{73.7}$ & 71.9 & 77.4 \\
\hline Sep-87 & 74.2 & 72.7 & 77.1 & Apr-91 & 77.3 & 74.8 & 82.6 \\
\hline Oct-87 & 74.2 & 72.5 & 77.5 & May-91 & 78.7 & 76.3 & 83.6 \\
\hline Nov-87 & 74.3 & 72.9 & 76.8 & Jun-91 & 75.5 & 72.0 & 82.8 \\
\hline Dec-87 & 76.7 & 76.0 & 77.6 & Jul-91 & 80.8 & 79.1 & 84.3 \\
\hline Jan-88 & 74.8 & 73.5 & 77.2 & Aug-91 & 81.8 & 79.8 & 85.7 \\
\hline Feb-88 & $P_{78.5}$ & 77.2 & 80.8 & Sep-91 & 82.3 & 80.1 & 86.6 \\
\hline Mar-88 & 76.9 & 75.7 & 79.0 & Oct-91 & 83.9 & 82.8 & 86.1 \\
\hline Apr-88 & 76.4 & 74.7 & 79.6 & Nov-91 & 80.9 & 79.5 & 83.7 \\
\hline May-88 & 75.8 & 74.2 & 78.8 & Dec-91 & 80.2 & 77.0 & 86.5 \\
\hline Jun-88 & 77.7 & 76.5 & 79.8 & Jan-92 & 82.6 & 81.6 & 84.6 \\
\hline Jul-88 & 75.5 & 73.4 & 79.8 & Feb-92 & 83.2 & 81.8 & 86.0 \\
\hline Aug-88 & 77.0 & 74.6 & 82.0 & Mar-92 & 82.1 & 81.7 & 82.9 \\
\hline Sep-88 & 78.2 & 76.7 & 80.9 & Apr-92 & 82.4 & 82.3 & 82.4 \\
\hline Oct-88 & 75.7 & 73.2 & 80.6 & May-92 & 82.2 & 81.3 & 84.1 \\
\hline Nov-88 & 77.9 & 76.1 & 81.4 & Jun-92 & 83.9 & 81.8 & 88.4 \\
\hline Dec-88 & 79.4 & 78.9 & 79.8 & Jul-92 & 87.9 & 86.3 & 91.1 \\
\hline Jan-89 & 77.1 & 75.0 & 81.2 & Aug-92 & 84.5 & 81.3 & 91.0 \\
\hline Feb-89 & 76.4 & 74.8 & 79.5 & Sep-92 & 86.2 & 83.6 & 91.5 \\
\hline Mar-89 & 76.4 & 74.4 & 80.2 & Oct-92 & 85.7 & 84.6 & 88.1 \\
\hline Apr-89 & 75.0 & 73.3 & 78.4 & Nov-92 & 84.0 & 82.6 & 87.1 \\
\hline May-89 & 76.4 & 74.4 & 80.4 & Dec-92 & 85.5 & 84.6 & 87.6 \\
\hline Jun-89 & 77.5 & 74.8 & 83.0 & Jan-93 & 85.3 & 84.3 & 87.4 \\
\hline Jul-89 & 73.8 & 69.7 & 82.2 & Feb-93 & 84.5 & 83.7 & 86.4 \\
\hline Aug-89 & 76.8 & 73.2 & 84.3 & Mar-93 & 85.7 & 85.8 & 85.7 \\
\hline Sep-89 & 77.1 & 73.8 & 83.7 & Apr-93 & 86.8 & 86.7 & 87.3 \\
\hline Oct-89 & 76.1 & 72.6 & 83.4 & May-93 & 84.7 & 83.5 & 87.2 \\
\hline Nov-89 & 77.6 & 74.0 & 85.0 & Jun-93 & 86.0 & 86.0 & 86.0 \\
\hline Dec-89 & 77.2 & 74.4 & 82.8 & Jul-93 & 85.9 & 85.1 & 87.5 \\
\hline Jan-90 & 77.8 & 74.0 & 85.6 & Aug-93 & 85.5 & 84.4 & 87.7 \\
\hline \multirow[t]{2}{*}{ Feb-90 } & 78.8 & 75.7 & 85.2 & Sep-93 & 89.2 & 88.0 & 91.6 \\
\hline & & & & Key: P & $\mathrm{T}=$ trough. & & \\
\hline
\end{tabular}




\begin{tabular}{|c|c|c|c|c|c|c|c|}
\hline \multicolumn{8}{|c|}{$\begin{array}{l}\text { Monthly Values of Transportation } \\
\text { Indexes (continued) }\end{array}$} \\
\hline Time & $\begin{array}{l}\text { Total } \\
\text { Transportation } \\
\text { Index }\end{array}$ & $\begin{array}{l}\text { Freight } \\
\text { Transportation } \\
\text { Index }\end{array}$ & $\begin{array}{l}\text { Passenger } \\
\text { Transportation } \\
\text { Index }\end{array}$ & Time & $\begin{array}{l}\text { Total } \\
\text { Transportation } \\
\text { Index }\end{array}$ & $\begin{array}{l}\text { Freight } \\
\text { Transportation } \\
\text { Index }\end{array}$ & $\begin{array}{l}\text { Passenger } \\
\text { Transportation } \\
\text { Index }\end{array}$ \\
\hline Oct-93 & 88.7 & 87.3 & 91.8 & May-97 & 105.5 & 106.5 & 103.8 \\
\hline Nov-93 & 90.3 & 90.0 & 91.1 & Jun-97 & 103.7 & 104.7 & 101.8 \\
\hline Dec-93 & 89.7 & 89.6 & 90.0 & Jul-97 & 106.4 & 108.4 & 102.7 \\
\hline Jan-94 & 86.7 & 85.9 & 88.3 & Aug-97 & 105.3 & 107.2 & 101.8 \\
\hline Feb-94 & 87.9 & 87.7 & 88.5 & Sep-97 & 109.8 & 111.2 & 107.2 \\
\hline Mar-94 & 93.5 & 95.0 & 90.8 & Oct-97 & 110.6 & 112.6 & 106.9 \\
\hline Apr-94 & 84.5 & 81.9 & 89.5 & Nov-97 & 106.9 & 107.3 & 106.1 \\
\hline May-94 & 91.4 & 91.8 & 90.7 & Dec-97 & 110.9 & 113.1 & 106.9 \\
\hline Jun-94 & 93.4 & 94.8 & 91.0 & Jan-98 & 110.3 & 112.9 & 105.6 \\
\hline Jul-94 & 91.7 & 91.8 & 91.8 & Feb-98 & 110.5 & 112.7 & 106.7 \\
\hline Aug-94 & 93.8 & 95.3 & 90.9 & Mar-98 & 112.0 & 115.4 & 105.8 \\
\hline Sep-94 & 97.0 & 97.3 & 96.4 & Apr-98 & 112.7 & 114.9 & 108.8 \\
\hline Oct-94 & 94.4 & 93.9 & 95.5 & May-98 & 111.9 & 114.1 & 108.1 \\
\hline Nov-94 & 99.7 & 101.5 & 96.3 & Jun-98 & 113.1 & 117.6 & 105.1 \\
\hline Dec-94 & $P_{104.6}$ & 110.0 & 94.5 & Jul-98 & 113.2 & 118.1 & 104.5 \\
\hline Jan-95 & 101.4 & 105.2 & 94.3 & Aug-98 & 110.3 & 114.4 & 103.1 \\
\hline Feb-95 & 100.6 & 104.7 & 92.8 & Sep-98 & 112.6 & 115.6 & 107.1 \\
\hline Mar-95 & 100.3 & 103.8 & 93.7 & Oct-98 & 114.0 & 115.6 & 111.1 \\
\hline Apr-95 & 94.4 & 95.0 & 93.3 & Nov-98 & 113.2 & 114.4 & 111.1 \\
\hline May-95 & 99.1 & 102.1 & 93.4 & Dec-98 & 114.3 & 117.0 & 109.4 \\
\hline Jun-95 & 98.0 & 100.6 & 93.1 & Jan-99 & 112.4 & 114.2 & 109.2 \\
\hline Jul-95 & ${ }^{\top} 94.2$ & 94.9 & 92.7 & Feb-99 & 114.4 & 116.7 & 110.5 \\
\hline Aug-95 & 99.9 & 103.6 & 93.0 & Mar-99 & 119.4 & 123.5 & 112.2 \\
\hline Sep-95 & 99.2 & 100.1 & 97.6 & Apr-99 & 116.3 & 118.0 & 113.4 \\
\hline Oct-95 & 97.1 & 97.1 & 97.2 & May-99 & 115.1 & 117.2 & 111.3 \\
\hline Nov-95 & 99.1 & 99.3 & 98.7 & Jun-99 & 116.8 & 120.3 & 110.7 \\
\hline Dec-95 & 95.7 & 95.8 & 95.4 & Jul-99 & 116.1 & 118.5 & 112.0 \\
\hline Jan-96 & 96.9 & 97.7 & 95.4 & Aug-99 & 116.7 & 121.7 & 107.8 \\
\hline Feb-96 & 100.0 & 98.8 & 102.3 & Sep-99 & 119.1 & 121.5 & 114.9 \\
\hline Mar-96 & 99.0 & 98.7 & 99.6 & Oct-99 & 118.3 & 118.5 & 118.0 \\
\hline Apr-96 & 98.6 & 98.4 & 98.7 & Nov-99 & $P_{121.8}$ & 122.9 & 119.8 \\
\hline May-96 & 101.5 & 102.5 & 99.7 & Dec-99 & 120.0 & 124.4 & 112.3 \\
\hline Jun-96 & 97.5 & 97.2 & 98.2 & Jan-00 & 117.6 & 121.2 & 111.3 \\
\hline Jul-96 & 100.0 & 100.7 & 98.8 & Feb-00 & 121.4 & 123.0 & 118.7 \\
\hline Aug-96 & 100.5 & 101.5 & 98.8 & Mar-00 & 119.4 & 120.0 & 118.5 \\
\hline Sep-96 & 99.9 & 99.0 & 101.6 & Apr-00 & 112.6 & 108.3 & 120.2 \\
\hline Oct-96 & 102.9 & 102.8 & 102.9 & May-00 & 120.0 & 119.3 & 121.5 \\
\hline Nov-96 & 101.5 & 102.2 & 100.3 & Jun-00 & 117.8 & 116.7 & 119.8 \\
\hline Dec-96 & 101.6 & 100.4 & 103.6 & Jul-00 & 114.1 & 112.2 & 117.6 \\
\hline Jan-97 & 104.5 & 104.9 & 103.7 & Aug-00 & 118.9 & 122.1 & 113.3 \\
\hline Feb-97 & 104.1 & 104.2 & 104.0 & Sep-00 & 115.6 & 112.9 & 120.3 \\
\hline Mar-97 & 103.4 & 102.4 & 105.2 & Oct-00 & 116.8 & 114.4 & 121.1 \\
\hline \multirow[t]{2}{*}{ Apr-97 } & 105.0 & 105.9 & 103.3 & Nov-00 & 118.7 & 115.4 & 124.7 \\
\hline & & & & Key: $P=$ & ak; $\mathrm{T}=$ trough & & \\
\hline
\end{tabular}




\begin{tabular}{|c|c|c|c|}
\hline Time & $\begin{array}{c}\text { Total } \\
\text { Transportation } \\
\text { Index }\end{array}$ & $\begin{array}{c}\text { Freight } \\
\text { Transportation } \\
\text { Index }\end{array}$ & $\begin{array}{c}\text { Passenger } \\
\text { Transportatior } \\
\text { Index }\end{array}$ \\
\hline Dec-00 & 112.3 & 109.3 & 117.7 \\
\hline Jan-01 & 118.8 & 119.0 & 118.6 \\
\hline Feb-01 & 114.5 & 111.9 & 119.3 \\
\hline Mar-01 & 118.2 & 117.0 & 120.4 \\
\hline Apr-01 & 115.5 & 111.7 & 122.5 \\
\hline May-01 & 120.9 & 121.1 & 120.6 \\
\hline Jun-01 & 115.5 & 113.3 & 119.5 \\
\hline Jul-01 & 116.6 & 115.2 & 119.3 \\
\hline Aug-01 & 120.2 & 122.5 & 116.4 \\
\hline Sep-01 & ${ }^{\top}{ }_{101.6}$ & 108.4 & 90.0 \\
\hline Oct-01 & 108.8 & 115.5 & 97.2 \\
\hline Nov-01 & 110.1 & 113.1 & 104.9 \\
\hline Dec-01 & 108.6 & 110.4 & 105.6 \\
\hline Jan-02 & 114.7 & 119.5 & 106.3 \\
\hline Feb-02 & 110.7 & 111.5 & 109.6 \\
\hline Mar-02 & 112.5 & 112.9 & 112.0 \\
\hline Apr-02 & 116.3 & 120.0 & 109.9 \\
\hline
\end{tabular}

Key: $\mathrm{T}=$ trough. 